\title{
Agent-based modeling of environment-migration linkages: a review
}

\author{
Jule Thober $^{1}, \underline{\text { Nina Schwarz }}^{1,2}$ and $\underline{\text { Kathleen Hermans }}^{1,3}$
}

\begin{abstract}
Environmental change can lead to human migration and vice versa. Agent-based models (ABMs) are valuable tools to study these linkages because they can represent individual migration decisions of human actors. Indeed, there is an increasing, yet small, number of ABMs that consider the natural environment in rural migration processes. Therefore, we reviewed $15 \mathrm{ABMs}$ of environment-migration linkages in rural contexts to synthesize the current state of the art. The reviewed ABMs are mostly applied in tropical contexts, serve a wide range of purposes, and cover diverse scales and types of environmental factors, migration processes, and social-ecological feedbacks. We identified potential for future model development with respect to the (1) complexity of environmental influence factors, (2) representation of relevant migration flows, and (3) type of social-ecological couplings. We found that existing models tend to not include fully integrated feedbacks and provide recommendations for the further development of ABMs to contribute to an understanding of the environment-migration-nexus in the future.
\end{abstract}

Key Words: agent-based modeling; environmental change; fully integrated feedbacks; migration; review; social-ecological system

\section{INTRODUCTION}

Environmental change puts tremendous pressure on socialecological systems. This applies in particular to contexts in which humans both depend on natural resources and affect them. Changes in precipitation patterns, including occurrences of droughts, floods, and sea level rise, pose some of the biggest challenges of environmental change for societies. In addition, the pressure on social-ecological systems is potentially exacerbated by demographic and economic dynamics, such as a growing population or changing market prices. One strategy to deal with these challenges is human migration, including rural-to-urban as well as rural-to-rural migration. The latter is of particular importance in developing countries (Bilsborrow 2002, Zimmerer 2004) where an increasing demand for labor during harvest times pulls people to rural areas.

Besides being triggered by environmental change, migration can also have environmental consequences, including deforestation and degradation of natural resources (Bilsborrow 2002, Carr 2009, Lambin and Meyfroidt 2011). For example, in a global-scale study, Neumann-Hermans et al. (2016) found the strongest forest resource degradation in those villages that were characterized by immigration. In addition to the impacts on the destination, the place of origin can experience environmental consequences of out-migration, for example through changes in land use practices such as a lack of maintenance of terraces causing soil erosion (Collins 1986), reduced intensification through population decline (Preston 1998), or remittances impacting the use of forest resources (Hecht et al. 2015). In summary, indications exist that environmental change, combined with a bundle of socioeconomic factors, can lead to migration which, in turn, can trigger additional environmental change (de Sherbinin et al. 2008, Foresight 2011).

There is a growing body of literature on environment-migration linkages based on an emerging number of case studies, and major strides were made with respect to theory development (e.g., Black et al. 2011, McLeman 2013a, 2017, Hunter et al. 2015). Still, considerable research gaps exist regarding the interplay of environmental and nonenvironmental migration determinants as well as regarding the social-ecological impacts of environmentally induced migration at both the migrant's destination and the place of origin (Hunter et al. 2015). Overall, there is a lack of understanding on how environmental changes and migration mutually reinforce each other.

Simulation models have the potential to address these gaps (McLeman 2013b, Neumann and Hilderink 2015). They can explicitly include feedbacks between the social and the ecological system and enable the simulation of future trajectories under different scenarios. Aggregated modeling approaches include the work of Krol and Bronstert (2007) who simulated linkages between climate change, water availability, agricultural economy, and migration for northeast Brazil. The authors conclude that migration is largely driven by mean municipality income being a function of climate change, water availability, and agricultural yields. In a recent study, Rigaud et al. (2018) integrated the shared socioeconomic pathway (SSP) narratives in a gravity model to estimate flows of people who left their home because of sea level rise, water availability, and crop productivity decline. Modeling results show that by 2050, approximately 140 million people across sub-Saharan Africa, Latin America, and South Asia could be forced to move within their own countries as consequence of climate change.

Together, these studies represent a valuable contribution to the exploration of possible future trajectories of climate induced migration by covering large regions. Yet, they tend to disregard that migration emerges from the complex decision making of heterogeneous individuals and their interactions. It is this importance of individual behavior that brings our attention to agent-based modeling. Agent-based models (ABMs) with their ability to depict how individual decision processes lead to changes at the population level are valuable tools in the discipline of

\footnotetext{
${ }^{1}$ Helmholtz Centre for Environmental Research - UFZ, Department of Computational Landscape Ecology, Leipzig, Germany, ${ }^{2}$ University of Twente, Faculty of Geo-Information Science and Earth Observation (ITC), Enschede, The Netherlands, ${ }^{3}$ Laboratory of Geo-Information Science and Remote Sensing, Wageningen University \& Research, Wageningen, The Netherlands
} 
demography (Willekens et al. 2017). What is equally important for studying environmentally induced migration is the capability of ABMs to represent social-ecological feedbacks in complex social-ecological systems (Schlüter et al. 2012). This is why ABMs have been widely used to study land use/land cover change (Parker et al. 2003, Matthews et al. 2007, Groeneveld et al. 2017), ecosystem and environmental management (Bousquet and Le Page 2004, Kelly et al. 2013), and various types of mobility and flight (Huang et al. 2014, Hattle et al. 2016, Suleimenova et al. 2017). As such, the capability of including social-ecological feedbacks makes ABMs a valuable tool for exploring the environment-migration nexus, which is reflected by the recently increasing, yet small, number of ABMs that consider the role of the natural environment in rural migration processes ${ }^{[1]}$ (cf. McLeman 2013b, Klabunde and Willekens 2016).

Therefore, it is time to systematically review existing ABMs of environment-migration linkages to further advance the development of ABMs in this field. Our research objectives are first, to provide a conceptual framework for social-ecological systems connected by human migration for describing and comparing ABMs. Building upon this framework, we provide a classification for one-way linkages, partly integrated linkages, and fully integrated two-way linkages in the system. Second, we review 15 existing ABMs on rural migration processes to synthesize the current practice in agent-based modeling of environmentmigration linkages. In particular, we address the following research questions:

1. Which migration processes have been studied with ABMs, e.g., in- and/or out-migration, return?

2. Which environmental, economic, and social influence factors of migration decisions are considered in existing ABMs and how?

3. How are social and ecological systems coupled in ABMs of environment-migration contexts? In particular, are environmental consequences of migration studied with ABMs?

4. Do conceptual gaps of modeling environment-migration linkages exist, and if so, what are the reasons?

Finally, we provide directions for further ABM development.

\section{METHODS}

\section{Conceptual framework}

We developed a conceptual framework of social-ecological systems that are connected through human migration. Here, all possible migration flows, i.e., into, between, and out of the subsystems, as well as the social-ecological interactions within each subsystem are considered (Fig. 1).

The overall system consists of subsystems (A and B). For simplicity reasons we refer to two subsystems; in principle each subsystem can represent more than one origin or destination system. In both subsystems, humans interact with the natural environment. In terms of migration flows, subsystems are characterized by out-migration from subsystem A to subsystem $\mathrm{B}$ and/or return-migration from subsystem B to subsystem A. Furthermore, persons can enter subsystems (migration into the system) and/or leave them (migration out of the system). In modeling terms, this process implies that agents are newly initialized or deleted in the course of the simulation. In other words, a person that sends remittances or information to its place of origin does not migrate out of the system but stays within the system.

Fig. 1. Conceptual framework of coupled social-ecological systems connected through migration. Tree and rain cloud represent the natural environment and the stick man represents the human actor; each of the subsystems can represent more than one origin or destination system.

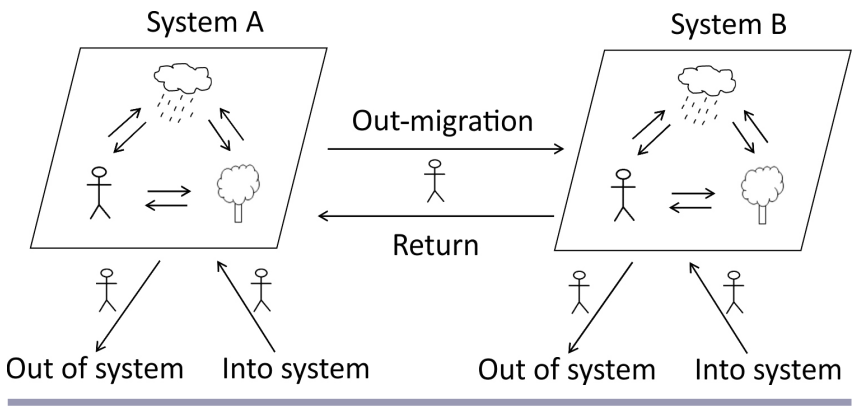

Box 1:

To represent the interactions within the subsystems we adapted Parker et al. (2008) and differentiate between one-way linkages, partly integrated linkages, and fully integrated two-way linkages:

- For one-way linkages, agents are influenced by the environment but do not influence it vice versa.

- In the case of partly integrated linkages, agents make natural resource-use decisions and are in turn influenced by them in their migration decision. For example, agents harvest natural resources in and are influenced in their migration decision via the harvest success. Importantly, the agents' decisions have no lasting impact on the environment; hence, there is no closed-loop feedback between the environmental and the human system.

- Fully integrated two-way linkages imply that environmental consequences of natural resource use and migration decisions are considered within the model, e.g., resource depletion or soil degradation.

The different types of linkages have been included in well-known stylized ABMs of social-ecological systems. Both partly integrated and fully integrated linkages are present in different versions of the Sugarscape model (Epstein and Axtell 1996). In Sugarscape, the landscape comprises cells with various amounts of sugar. In each time step, agents stay put or move to an unoccupied cell and then consume all the sugar available on their current location. In the version with immediate grow back, the sugar completely regrows to its maximum in the next time step, thus forms a partly integrated linkage. A fully integrated two-way linkage is present in gradual grow back because the amount of sugar increases only incrementally in each time step. Thus, agents have an impact on the availability of natural resources of the following time steps. According to our knowledge, no well-known one-way integrated version of Sugarscape exists, but could be imagined in a way that agents are attracted by different amounts of sugar, but do not actually consume it. 
The purpose of this framework is to enable us to describe and compare ABMs on environmentally induced migration with regard to the linkages within and between the subsystems. Therefore, our framework is complementary to generic standards for describing ABMs such as the ODD+D framework (Müller et al. 2013). The ODD $+\mathrm{D}$ framework addresses modeling choices such as temporal and spatial scales, various model design concepts, and details of human decision making. However, because of this broad scope, the ODD+D framework does not consider specific aspects that need to be addressed in ABMs for environmentally induced migration such as types of migration flows. While focusing on describing and comparing ABMs, our framework does not provide guidelines for model testing and analysis. For this, frameworks such as the TRACE (TRAnsparent and Comprehensive model Evaludation) framework (Schmolke et al. 2010, Grimm et al. 2014) for documenting the development and testing of models represent valuable complements to our framework.

\section{Paper selection}

In March 2017, we performed a Web of Science topic search to obtain a systematic and unbiased literature selection. For this purpose, we adapted the search term proposed by Klabunde and Willekens (2016) to include a wide range of synonyms used for the method of ABMs (see Table 1). We did not restrict our search to a certain period of publication.

Table 1. Search terms used for the Web of Science topic search.

\begin{tabular}{l}
\hline Search terms \\
\hline Included \\
agent-based model* OR agent-based simulation OR (agent \\
AND based AND model*) OR (multi AND agent); migration \\
Excluded \\
cancer OR medicine OR tumour OR disease OR therap*; \\
server OR sensor; chemi*OR biolog*OR mineral*OR seismic*
\end{tabular}

From the resulting 508 articles we extracted those publications describing ABMs in which migration decisions in rural contexts are influenced by at least one environmental factor, e.g., rainfall. We excluded urban-urban migration as well as constantly moving societies including pastoralists, hunter and gatherers. This led to 14 publications.

We complemented this set by considering the non-ISI listed Journal of Land Use Science, which is an important outlet for ABMs. This step resulted in one additional publication. Furthermore, we included four relevant papers identified by Klabunde and Willekens (2016) and within our own network. Additionally, we added two non-ISI-listed technical reports as additional references for two of the identified publications because they provided a more detailed model description than the respective ISI-listed publication. Finally, we checked all publications that cited the review of Klabunde and Willekens (2016) and performed a Web of Science topic search using "microsimulation" instead of "agent-based model" and "mobility" and "movement" instead of "migration." Both steps did not result in additional ABMs fulfilling our consideration criteria described above. As a result, 21 publications describing 15 ABMs were considered for this review.

\section{Model categorization}

We reviewed the identified $15 \mathrm{ABM}$ according to the conceptual framework described above and according to the categories listed in Table 2. We developed a standardized protocol for categorizing the models and investigating how rural migration is modeled. Based on the conceptual diagram we additionally drafted diagrams for each ABM to visualize the considered processes; the diagrams for each of the ABMs can be found in the Appendix 1. Each ABM was categorized by two authors of this article and we subsequently sent our results to the developer of the ABM for an additional cross-check. This final step enabled us to eradicate possible misinterpretations; the response rate was $87 \%$.

The following definitions were used for classifying the ABMs:

Context-specific conceptual model: In a context-specific ABM, model processes are based on data or expert knowledge specific to a case study, represented in a stylized model; however, it is not based on a specific geographic region or spatially explicit data (based on Groeneveld et al. 2017).

Migration flows: Systems can be characterized by out-migration from subsystem A to subsystem B and return-migration from subsystem B to subsystem A. In the latter case, agents can move directly back to the origin (direct return) or do so via multiple stops (indirect return). Furthermore, humans can in-migrate from outside the two subsystems into subsystem $\mathrm{A}$ and/or B and humans can out-migrate from subsystem A and/or B to somewhere outside the overall system. Migration was only classified as "out of system" for agents that had no opportunity of returning within the model setup and did not interact with their origin system by sending information or remittances.

Duration of migration (seasonal/permanent): We differentiate between seasonal and permanent migration. Seasonal migration is characterized by short-term absence, i.e., less than a year, from the place of origin. In the context of natural resource use, this type of migration is often aligned to harvest cycles. In the case of permanent migration, migrants leave with the intention to stay for long-term periods. However, it is not precluded that they move on or return after a short-term because of changing conditions.

Properties of the destination system known: This indicates whether the agents consider properties of the destination system, e.g., availability of natural resources or market prices in the destination system, in their decision to migrate there.

Direct/indirect environmental influence factors: We assessed whether environmental influence factors are conceptualized as direct, e.g., agents consider amount of precipitation when deciding to migrate or not, or indirect drivers, e.g., rainfall affects income, which agents consider when deciding whether to migrate or not.

Abiotic/biotic: Abiotic are all environmental factors that are not influenced by living organism, e.g., climate, atmosphere, temperature, light. Biotic are all environmental factors that are influenced by living organisms, e.g., plant growth, soil quality.

Social network: Social networks are explicitly modeled social linkages, e.g., through remittance, information exchange, dependents. If agents compare their own situation with that of others or consider the impact a decision has on others, it is not considered a network effect. 
Table 2. Categories to classify the reviewed agent-based models. The ${ }^{\dagger}$ marks terms that are explained in the text.

\begin{tabular}{|c|c|c|}
\hline & Category & Response options \\
\hline \multirow[t]{5}{*}{ General model characteristics } & Model purpose & $\begin{array}{l}\text { System understanding, prediction (quantitative), management or decision support, } \\
\text { communication (participatory approaches), theory development, hypothesis testing, } \\
\text { not clearly stated }\end{array}$ \\
\hline & Case study & Yes, no, context-specific conceptual model ${ }^{\dagger}$ \\
\hline & & Indicate the location of case study \\
\hline & Spatial scale & Indicate the extent and resolution \\
\hline & Temporal scale & Indicate the extent and resolution \\
\hline \multirow[t]{3}{*}{ Migration process } & Migration flow $^{\dagger}$ & Out-migration, direct return, indirect return, out of system, into system \\
\hline & $\begin{array}{l}\text { Properties of the destination system } \\
\text { known }^{\dagger}\end{array}$ & Yes, no \\
\hline & Duration $^{\dagger}$ & Seasonal, permanent, both \\
\hline \multirow[t]{4}{*}{ Environmental influence factors } & Influence $^{\dagger}$ & Direct, indirect \\
\hline & Number of factors & Indicate the total number of factors included \\
\hline & Which factors & Indicate the factors \\
\hline & Type $^{\dagger}$ & Abiotic, biotic \\
\hline \multirow[t]{4}{*}{ Other influence factors } & Type & Economic, social, both \\
\hline & Which factors & Indicate the factors \\
\hline & Social network ${ }^{\dagger}$ & Yes, no \\
\hline & & Indicate how networks were modeled \\
\hline Social-ecological feedbacks & Type of coupling ${ }^{\dagger}$ & One-way linkage, partly integrated, fully integrated \\
\hline \multirow[t]{3}{*}{ Decision making } & $\begin{array}{l}\text { Methodology for simulating } \\
\text { migration decision }\end{array}$ & Probability function, decision theory, heuristics, optimization \\
\hline & $\begin{array}{l}\text { Other decision processes besides } \\
\text { migration decision }\end{array}$ & Cropping, livestock, hunting, others, none \\
\hline & Others & Indicate which other decision processes are included \\
\hline
\end{tabular}

Social-ecological feedbacks (one-way linkages/partly integrated linkages/fully integrated two-way linkages): We assessed the models following the classification introduced with our conceptual framework.

Migration decision (probability function/decision theory/ heuristics/optimization): We assessed the approach used for simulating a migration decision. A "probability function" can be any function that includes a stochastic factor to determine the migration decision, e.g., random destination, logistic regression function. Models that are based on "decision theory" use an existing decision theory from economics, psychology, or other fields, e.g., Theory of Planned Behavior. "Heuristics" are simple decision rules or rules of thumb, e.g., the if-then rule. "Optimization" includes any form of maximization of a certain indicator, e.g., income, fitness, happiness.

\section{RESULTS AND DISCUSSION}

\section{Overview}

The number of ABMs that resulted from our literature search is substantially lower than the 27 ABMs reviewed by Klabunde and Willekens (2016) who analyzed migration ABMs in general. This indicates that a substantial share of ABMs in the field of migration does not consider environmental factors.

Table 3 provides an overview of the 15 reviewed models. All considered ABMs are used for gaining system understanding, which is in line with other fields of ABMs (e.g. land use ABMs reviewed by Groeneveld et al. 2017). Four ABMs are used within participatory contexts (e.g. Naivinit et al. 2010, Wu et al. 2011), three to provide decision support (e.g. Smajgl and Bohensky 2013) and three for predicting numbers of migrants (e.g. Berman et al. 2004, Hassani-Mahmooei and Parris 2012).
The temporal scales of the reviewed models range from small, e.g., three years in daily time steps in Naqvi and Rehm (2014), to large, e.g., 10,000 years in yearly time steps in Janssen (2010). Numerous models applied different time steps for simulating different processes and, thereby, tackle the challenge of subsystems operating at different temporal scales as discussed by Martin and Schlüter (2015). For example, Smajgl and Bohensky (2013) use daily time steps for capturing environmental processes and weekly time steps for household-level processes such as migration. In this case, migration processes are modeled with a coarser temporal resolution than the remaining model processes.

The spatial scales cover a wide range from local (e.g., Naivinit et al. 2010) to national extent (e.g., Kniveton et al. 2011). The majority of reviewed ABMs consider a specific case study (Table 3). The locations of the case studies are distributed across the tropics with a focus in Southeast Asia (Fig. 2). This might indicate that environmental factors or natural resources are linked with human migration especially in this climate zone.

Fig. 2. Global distribution of model applications.

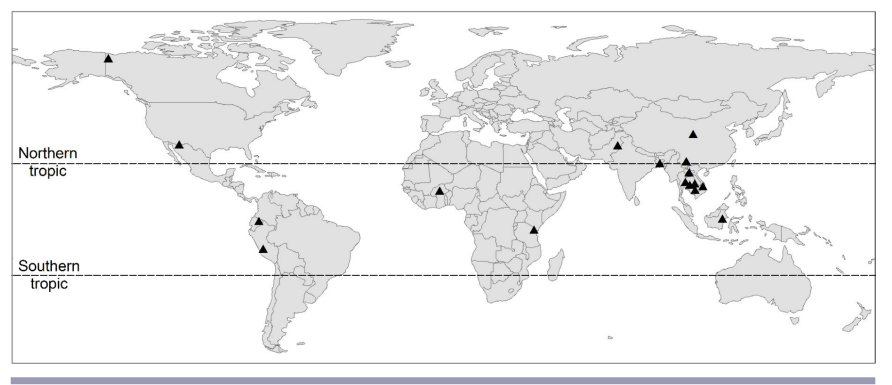


Table 3. Summary of the reviewed agent-based models; the full categorization of each model can be found in the Appendix 1.

\begin{tabular}{|c|c|c|c|}
\hline Reference(s); model name & Case study & Migration flow & Environmental influence factors (number; type) \\
\hline Berman et al. 2004 & Old Crow, Yukon, Canada & Out-migration, direct return & 2; climate warming, caribou numbers \\
\hline $\begin{array}{l}\text { Hadzibeganovic and Xia } \\
2016\end{array}$ & None & Out-migration, into system & 1; resource availability (food source) \\
\hline $\begin{array}{l}\text { Hassani-Mahmooei and } \\
\text { Parris } 2012\end{array}$ & Bangladesh & $\begin{array}{l}\text { Out-migration, indirect } \\
\text { return }\end{array}$ & $\begin{array}{l}4 \text { combined in } 1 \text {; climate shock represented by } \\
\text { combination of droughts, floods, cyclones, and sea level } \\
\text { rise }\end{array}$ \\
\hline Janssen 2010 & American Southwest & $\begin{array}{l}\text { Out-migration, indirect } \\
\text { return }\end{array}$ & 3; rainfall, soil quality depletion and recovery, harvest level \\
\hline $\begin{array}{l}\text { Kniveton et al. 2011, 2012; } \\
\text { AMARC }\end{array}$ & Burkina Faso & Out-migration, direct return & 1 ; rainfall \\
\hline $\begin{array}{l}\text { Magallanes et al. 2014; } \\
\text { WankaLab1 }\end{array}$ & Huancayo region, Peru & Out-migration & $\begin{array}{l}5 \text {; water availability, seasonal rainfall, glacier melt affected } \\
\text { by sunlight luminosity and glacier albedo }\end{array}$ \\
\hline Mena et al. 2011 & $\begin{array}{l}\text { Northern Ecuadorian } \\
\text { Amazon }\end{array}$ & Out-migration, direct return & $1 ;$ slope \\
\hline $\begin{array}{l}\text { Naivinit et al. 2010; } \\
\text { BanMakMai model }\end{array}$ & $\begin{array}{l}\text { Ban Mak Mai village, } \\
\text { northeast Thailand }\end{array}$ & Out-migration, direct return & 2 ; rainfall, rice productivity \\
\hline $\begin{array}{l}\text { Naqvi and Rehm 2014; } \\
\text { SHELscape }\end{array}$ & Punjab region, Pakistan & $\begin{array}{l}\text { Out-migration, indirect } \\
\text { return }\end{array}$ & $\begin{array}{l}2 \text {; abstract disaster (interpreted as flooding but not } \\
\text { modeled explicitly), food resource availability }\end{array}$ \\
\hline Rogers et al. 2011 & None & $\begin{array}{l}\text { Out-migration, indirect } \\
\text { return; out of system }\end{array}$ & 1 ; resource availability \\
\hline $\begin{array}{l}\text { Smajgl et al. 2009, Smajgl } \\
\text { and Bohensky 2013; } \\
\text { SimPaSI model }\end{array}$ & East Kalimantan, Indonesia & Out of system & 3; flooding, timber, fish scarcity \\
\hline $\begin{array}{l}\text { Smajgl et al. 2013, Smajgl et } \\
\text { al. } 2015 a, b ; \text { Mersim model }\end{array}$ & $\begin{array}{l}\text { Mekong region (Laos, } \\
\text { Cambodia, Yunnan Province } \\
\text { China, Thailand, Vietnam) }\end{array}$ & Out-migration & $\begin{array}{l}5 \text {; loss of fish catch, increasing weather variability, water } \\
\text { availability, more brackish water, small floods }\end{array}$ \\
\hline Smith 2014; RABMM-T & $\begin{array}{l}\text { Kilimanjaro Region, } \\
\text { Tanzania }\end{array}$ & Out-migration, direct return & 3 ; rainfall, crop yield, livestock stock \\
\hline $\begin{array}{l}\text { Entwisle et al. } 2008,2016 \text {, } \\
\text { Walsh et al. } 2013\end{array}$ & $\begin{array}{l}\text { Nang Rong District, } \\
\text { northeastern Thailand }\end{array}$ & Out-migration, direct return & 3 ; rainfall, soil quality and type, crop yield \\
\hline Wu et al. 2011 & China & $\begin{array}{l}\text { Out-migration, indirect } \\
\text { return }\end{array}$ & $\begin{array}{l}\text { 4; agricultural productivity, annual rainfall, annual average } \\
\text { temperature, presence of rivers }\end{array}$ \\
\hline
\end{tabular}

Figure 3 gives an overview of the framework's elements considered within the reviewed ABMs by counting the occurrences of the framework's elements. Hereby, framework elements are the interlinkages between the environmental factors and the agents, the various migration flows, as well as the origin and destination system.

Fig. 3. Conceptual diagram with the numbers beside the lines indicating the number of agent-based models considering the respective element; the tree represents the availability of natural resources, the rain cloud represents the influencing environmental factors, and the stick man represents the human agent

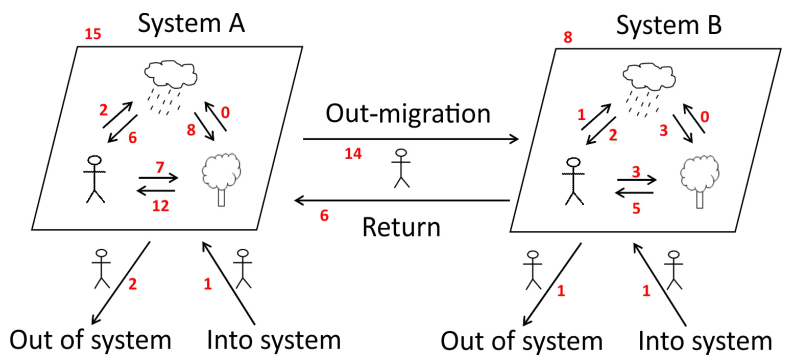

We grouped the environmental factors considered in the reviewed models (rightmost column in Table 3) into two types: the availability of (1) natural resources, i.e., provisioning services such as resource availability and (2) influencing environmental factors, i.e., mostly factors of environmental change such as rainfall. This distinction is illustrated in the diagram with the tree symbol (natural resources) and the rain cloud symbol (influencing environmental factor). Figure 3 shows that influencing environmental factors determine the availability of natural resources in a large number of models, e.g., soil quality affects crop yields in Janssen (2010). Both natural resources and influencing environmental factors may influence human agents in their decision to migrate. Furthermore, human agents frequently influence the availability of natural resources, e.g., consumption of resources in Hadzibeganovic and Xia (2016)). In contrast, human agents affecting influencing environmental factors is rarely included in the models, e.g., pollution affecting glacier processes in Magallanes et al. (2014).

\section{Types of migration processes}

Figure 3 shows that most reviewed ABMs consider out-migration from one subsystem with the option to return in the course of the simulation (e.g., Berman et al. 2004, Rogers et al. 2011). Two ABMs include migration out of the system (Rogers 2011, Smajgl et al. 2013) and one ABM allows for in-migration from outside 
Table 4. Environmental factors considered in the reviewed agent-based models.

\begin{tabular}{|c|c|c|c|c|c|c|c|c|c|c|c|c|c|c|c|}
\hline & \multicolumn{9}{|c|}{$\begin{array}{l}\text { Influencing environmental factors } \\
\text { (i.e. mostly factors of environmental change) }\end{array}$} & \multicolumn{6}{|c|}{ Availability of natural resources } \\
\hline & 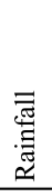 & 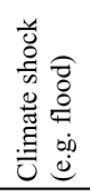 & 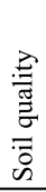 & 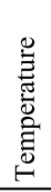 & 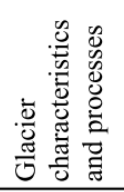 & 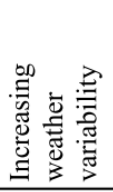 & 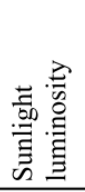 & $\frac{\check{\partial}}{\frac{\partial}{\alpha}}$ & 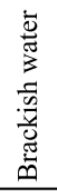 & $\begin{array}{l}\frac{7}{0} \\
\frac{\pi}{2} \\
0 \\
0 \\
0\end{array}$ & 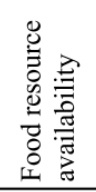 & 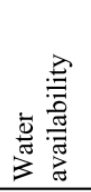 & 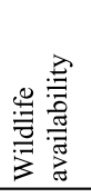 & $\begin{array}{l}\bar{\Xi} \\
\text { है } \\
\underline{\Xi}\end{array}$ & $\begin{array}{l}\frac{y}{0} \\
0 \\
0 \\
0 \\
0 \\
0\end{array}$ \\
\hline Berman et al. 2004 & & & & $\mathrm{x}$ & & & & & & & & & $\mathrm{x}$ & & \\
\hline Hadzibeganovic and Xia 2016 & & & & & & & & & & & $\mathrm{x}$ & & & & \\
\hline Hassani-Mahmooei and Parris 2012 & & $\mathrm{x}$ & & & & & & & & & & & & & \\
\hline Janssen 2010 & $\mathrm{x}$ & & $\mathrm{x}$ & & & & & & & & $\mathrm{x}$ & & & & \\
\hline Kniveton et al. 2011 & $\mathrm{x}$ & & & & & & & & & & & & & & \\
\hline Magallanes et al. 2014 & $\mathrm{x}$ & & & & $\mathrm{x}$ & & $\mathrm{x}$ & & & & & $\mathrm{x}$ & & & \\
\hline Mena et al. 2011 & & & & & & & & $\mathrm{x}$ & & & & & & & \\
\hline Naivinit et al. 2010 & $\mathrm{x}$ & & & & & & & & & $\mathrm{x}$ & & & & & \\
\hline Naqvi and Rehm 2014 & & $\mathrm{x}$ & & & & & & & & & $\mathrm{x}$ & & & & \\
\hline Rogers et al. 2011 & & & & & & & & & & & $\mathrm{x}$ & & & & \\
\hline Smajgl and Bohensky 2013 & & $\mathrm{x}$ & & & & & & & & & & & $\mathrm{x}$ & $\mathrm{x}$ & \\
\hline Smajgl et al. $2015 a$ & & $\mathrm{x}$ & & & & $\mathrm{x}$ & & & $\mathrm{x}$ & & & $\mathrm{x}$ & $\mathrm{x}$ & & \\
\hline Smith 2004 & $\mathrm{x}$ & & & & & & & & & $\mathrm{x}$ & & & & & $\mathrm{x}$ \\
\hline Walsh et al. 2013 & $\mathrm{x}$ & & $\mathrm{x}$ & & & & & & & $\mathrm{x}$ & & & & & \\
\hline Wu et al. 2011 & $\mathrm{x}$ & & & $\mathrm{x}$ & & & & & & $\mathrm{x}$ & & $\mathrm{x}$ & & & \\
\hline Sum & 7 & 4 & 2 & 1 & 1 & 1 & 1 & 1 & 1 & 4 & 4 & 3 & 3 & 1 & 1 \\
\hline
\end{tabular}

the overall system (Hadzibeganovic and Xia 2016). The neglect of migration into and out of the system can be considered a particular strong simplification because, in reality, humans often leave and enter systems such as a country or a region (United Nations 2013). According to our definition, "migration out of system" does not include agents who leave their home and send remittances. Finally, the majority of reviewed ABMs consider permanent migration (see Appendix 1). In contrast, especially in rural areas in the tropics, seasonal migration during the lean season often plays an important role (Henry et al. 2004, Rademacher-Schulz et al. 2014) and there seems to be a lack of ABMs studying this crucial agricultural labor migration.

\section{Factors influencing migration decisions}

In eight ABMs, the properties of the destination system, also referred to as pull factors, are influencing the migration decision (indicated at the top left corner of subsystem B in Fig. 3). The number of environmental factors (being push or pull factors, or both) represented per ABM ranges from one to five (Table 3). In most ABMs, environmental factors are considered as indirect drivers (see Appendix 1). This is in line with Black et al. (2011) who conceptualized the indirect role of environmental influence factors in migration processes. In Table 4, we categorize environmental influence factors by the two types "influencing environmental factors" and "availability of natural resources."

Most of the 15 ABMs include both economic and social factors next to environmental factors and a few focus on either economic or social factors next to environmental factors. Four ABMs explicitly model social networks (Berman et al. 2004, Naivinit et al. 2010, Kniveton et al. 2011, Smith 2014). This rather limited representation might partly be due to our strict definition of social networks, but also reflects the complexity associated with modeling social networks. The most frequently considered economic influence factors are distance (to the nearest road, market, or the destination), assets (either on individual, household, or village level, e.g., land, TV, water pump), and income. Among the social influence factors, age, influence by peers (e.g., number of neighbors, fitness of neighbors, behaviors of neighbors, migration of others), gender, population size, migration experience, social ties (e.g., dependent at home), and education are most frequently accounted for. These influence factors are frequently discussed as migration drivers identified in empirical and conceptual studies on environment-migration linkages (e.g., Black et al. 2011, Morrissey 2013, Neumann and Hermans 2017). Interestingly, political influence factors, including discrimination, persecution, conflict, which are known to drive significant migration flows are underrepresented in ABMs, probably because data on how such factors shape individual decisions is scarce.

\section{Coupling of the social-ecological system}

We categorized the reviewed ABMs into one-way, partly integrated and fully integrated social-ecological feedbacks (cf. Parker et al. 2008). Table 5 shows the social-ecological feedback included in each of the 15 reviewed ABMs. In five ABMs we found 
Table 5. Causal chains representing the social-ecological feedbacks within the reviewed agent-based models (ABM); italic terms represent actions taken by the agents; the term in brackets applies only for parts of the causal chain, i.e., forest economy is affected by timber scarcity.

\begin{tabular}{|c|c|}
\hline $\mathrm{ABM}$ & Causal chain \\
\hline \multicolumn{2}{|l|}{ One-way linkage } \\
\hline Berman et al. 2004 & Climate warming $->$ Caribou numbers $->$ Hunting success $->$ Migration decisions \\
\hline Hassani-Mahmooei and Parris & Climate shocks -> Migration decision \\
\hline 2012 & \\
\hline Kniveton et al. 2011 & Rainfall -> Migration decision \\
\hline Smith 2004 & Rainfall -> Livestock and crop yield -> Income and food production $->$ Migration decision \\
\hline Wu et al. 2011 & Presence of rivers, rainfall and temperature -> Agricultural productivity $->$ Migration decision \\
\hline \multicolumn{2}{|l|}{ Partly integrated } \\
\hline Mena et al. 2011 & Slope -> Land use selection $->$ Assets -> Migration decision \\
\hline Naivinit et al. 2010 & Rainfall + Rice planting $->$ Rice growth $->$ Income $->$ Migration decision \\
\hline Naqvi and Rehm 2014 & Disaster + Food production $->$ Food resource availability $->$ Income $->$ Migration decision \\
\hline Walsh et al. 2013 & Rainfall, soil quality + Crop choice $->$ Crop yields $->$ Household assets $->$ Migration decisions \\
\hline \multicolumn{2}{|l|}{ Fully integrated } \\
\hline Hadzibeganovic and Xia 2016 & Resource availability $->$ Fitness $->$ Migration decision $->$ Resource availability \\
\hline Janssen 2010 & Soil quality + Rainfall -> Harvest level $->$ Migration decision $->$ Population density $->$ Soil quality \\
\hline Magallanes et al. 2014 & Rain, sunlight, albedo, glacier melts -> Water availability $->$ Comfort level -> Migration decisions $->$ Glacier melt \\
\hline Rogers et al. 2011 & Resource availability $->$ Migration decision $->$ Resource availability \\
\hline Smajgl and Bohensky 2013 & Flooding, fish scarcity, timber scarcity $->$ (Forest economy $->$ ) Migration decisions $->$ Fish scarcity, timber scarcity \\
\hline Smajgl et al. $2015 a$ & $\begin{array}{l}\text { Weather variability, floods, fish catch, brackish water and water availability }->\text { Migration decisions }->\text { Fish catch, } \\
\text { brackish water, water availability }\end{array}$ \\
\hline
\end{tabular}

one-way linkages, i.e., agents are influenced in their migration decision by the environment but do not influence it in turn. Four models include partly integrated linkages, e.g., agents alter land use and are in turn influenced by harvest success (Mena et al. 2011). Six ABMs implement fully integrated linkages and as such consider environmental change as both a cause and consequence of migration decisions, e.g., soil degradation in Janssen (2010).

Six out of 15 models consider fully integrated linkages; although the representation of these feedbacks between social and ecological systems is a strong advantage of ABMs (e.g., Matthews et al. 2007, Schlüter et al. 2012, Filatova et al. 2013) and is advocated in several scientific fields, such as land use modeling (Parker et al. 2008). Interactions between the social and environmental subsystem can either amplify or weaken a regime shift (Filatova et al. 2016), thus, omitting critical interactions could lead to missing or overemphasizing such regime shifts. Of course, it needs to be acknowledged that the incorporation of fully integrated linkages is not necessary in every case; if the system under study does not depend on social-ecological feedbacks, a one-way or partly integrated model can be sufficient, or even better suited, to answer the posed research questions. The important challenge in this respect is to identify crucial linkages, especially because they might occur across different scales and involve indirect feedbacks (Parker et al. 2008). If in doubt, including linkages in a model would allow modelers to check their importance in a sensitivity analysis.

Should fully integrated social-ecological feedbacks be required, implementing them most likely implies increasing the model complexity, possibly leading to reduced transparency (Müller et al. 2014) or difficulties regarding parameterization (Smajgl et al. 2011) and model analysis (Lee et al. 2015). A fully integrated model will be more difficult to understand, to parameterize, and to validate against real world data. This increased difficulty in model development and analysis is also indicated by our result that fully integrated ABMs contain a slightly higher number of environmental factors than one-way or partly integrated models. Yet, this insight is based on a limited number of models and therefore can only be seen as an indication rather than as statistically robust result.

\section{The challenge of matching the conceptual framework}

As visualized in Figure 3, some elements of our conceptual framework receive more attention than others. The number of considered framework elements per ABM is on average 6.4 out of the 20 framework elements. Here, we aim to shed light on the reasons for the limited number of framework elements per ABM and discuss how various model parts relate to each other. As such, we are particularly interested in how the representation of socialecological feedbacks is associated with the number of environmental factors or the representation of migration flows and migration decisions.

The number of environmental factors being included in the reviewed models is slightly higher for ABMs with fully integrated two-way linkages (Fig. 4) than for one-way and partly integrated ABMs. For example, Magallanes et al. (2014) implemented a fully integrated coupling that represents the complex biophysical process of water availability being affected by the interplay of human action and glacier processes (see Table 5). In Janssen (2010), the fully coupled process of humans affecting agricultural harvest levels via soil depletion is reflected in the larger number of environmental variables compared to the number of considered environmental factors in the other reviewed ABMs. In contrast, fully integrated models with low numbers of environmental factors also exist. For example, Rogers et al. (2011) present a fully integrated ABM with only one environmental factor. 
Fig. 4. Type of social-ecological coupling and the number of environmental factors included in the agent-based model. The white dot indicates the median; the bold bar indicates the first and the third quartiles.

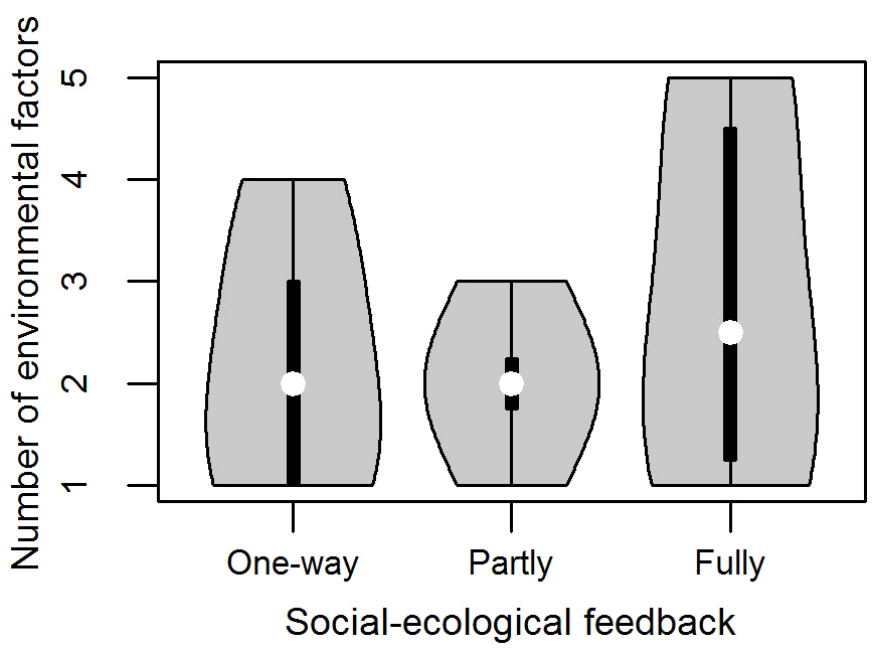

We identified a relationship between the type of coupling and the decision rules used to model migration decisions: decision models based on probability functions or decision theories are exclusively used in ABMs with one-way or partly integrated linkages (Fig. 5). For example, the one-way integrated models by Kniveton et al. (2011) and Smith (2014) use the Theory of Planned Behavior to model migration decisions (Ajzen 1985, 1991). In contrast, all ABMs with fully integrated linkages solely contain heuristics, i.e., simple decision rules or rules of thumb such as if-then rules. For example, in the fully integrated models by Smajgl et al. (2015a) and Smajgl and Bohensky (2013) migration decisions are based on Boolean variables, which were derived from interviews and households and indicate whether an agent would migrate in a particular situation, e.g., if fish scarcity exceeds a certain level. This relationship between type of coupling and the representation of migration decisions might hint at the challenges for combining complex decision rules with complex social-ecological feedbacks for model development. Here, the goal to model human decisions in general and migration decisions in particular in a comprehensive way in ABMs seems to challenge considering fully integrated feedbacks. Modeling human decisions to study social-ecological systems is of increasing importance (Groeneveld et al. 2017). Although progress such as the use of decision theories is being made (Schlüter et al. 2017), the flexibility and complexity of human decisions still represent major challenges for modeling.

All reviewed ABMs with one-way or partly integrated linkages consider out-migration together with an either direct or indirect return of migrants (Fig. 5). Yet, migration into or out of the system is solely included in fully integrated two-way integrated ABMs. This indicates that modelers seem to focus either on representing human decision making in as detailed a manner as possible, e.g., by using decision theories, see Groeneveld et al. 2017) or on representing fully integrated social-ecological feedbacks (see Filatova et al. 2013) and considering all possible migration flows.
One reason for this observation might be missing data and understanding of the complex environment-migration context. Bilsborrow and Henry (2012) state that, very seldom does sufficient data on both environmental factors and migration exist from the same region and the same time. The lack of input data has also been identified for ABMs in general (Schulze et al. 2017). For example, data on individual decision making would improve the representation of decision making in ABMs (Filatova et al. 2013). A second reason for the focus on specific model parts are challenges associated with analyzing complex models (Sun et al. 2016). The discussion of difficulties and strategies for analyzing complex ABMs has been gaining more and more attention recently (e.g., Polhill et al. 2016 for systemic change, Filatova et al. 2016 for regime shifts, Lee et al. 2015 and Buchmann et al. 2016 for empirical ABMs).

Fig. 5. Type of social-ecological coupling and the decision rule used to model migration decisions (left) and the migration flow considered within the agent-based model (right).
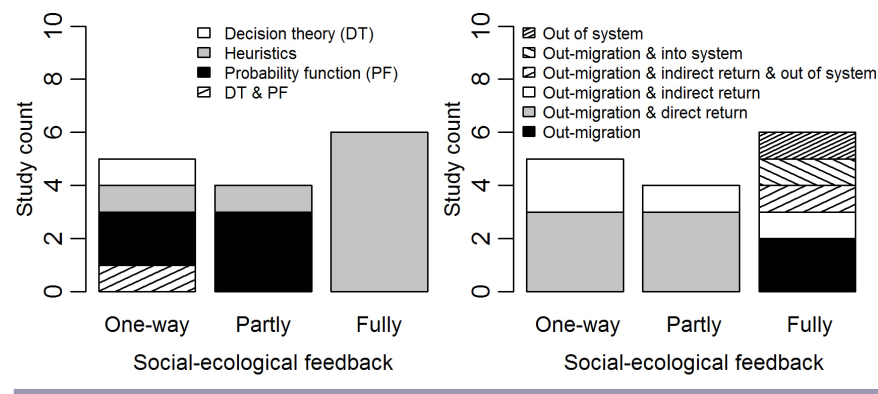

\section{Methodological considerations}

Categorizing ABMs based on provided model descriptions is always prone to subjective biases. To limit such biases and to mitigate possible misinterpretation, we did a cross-check within our author team as well as with the authors of the reviewed models. Advancing the practice of describing models by using standard protocols is a crucial step in tackling the challenge of model communication (e.g., Müller et al. 2013, 2014).

Categorizing ABMs requires the use of consistent definitions. Hence, the conclusions drawn from our review depend on the applied definitions. For example, our strict definition of social networks and of migration out of the system has contributed to the small numbers of ABMs in these categories. Similarly, in order to cover all relevant ABMs we applied a broad definition of environmental factors. For example, we categorized "crop yields" as natural resource, which could also be seen as an economic factor.

Finally, as we focused our review on ABMs of the environmentmigration-nexus in rural contexts of natural resource use, we applied a rigorous procedure of eliminating ABMs, including urban-urban migration and residential mobility. This led to a limited number of ABMs to review, which hampers a statistical analysis of the results.

\section{CONCLUSION}

In this study, we reviewed $15 \mathrm{ABMs}$ of environment-migration linkages to synthesize the current practice in this field and to further advance the model development. We provide a conceptual 
framework for social-ecological systems connected through human migration, which can be used for describing and comparing ABMs. In summary, we found that ABMs considering environment-migration linkages are still scarce. Given the importance of environment-migration linkages, we call for further developing ABMs of environment-migration linkages and would like to highlight promising ways forward in advancing this field. This also implies intensifying interdisciplinary work between social and natural scientists, modelers, and empiricists to appropriately depict human decision making in such ABMs and to understand and represent linkages of social and ecological systems.

Most reviewed ABMs represent case studies in the tropics, serve a wide range of model purposes, and cover diverse spatiotemporal scales. Based on our analysis, we identified major gaps with respect to modeling environment-migration linkages. First, important migration flows such as migration into and out of the system as well as temporary migration processes currently receive little attention in ABMs of environment-migration linkages. Furthermore, 9 out of 15 models lack fully integrated socialecological feedbacks. Exploiting the potential of social-ecological models by implementing more fully coupled systems is essential for exploring whether environmental changes and migration mutually reinforce each other, although drawbacks such as increasing model complexity exist.

To close these gaps, standards for developing and analyzing ABMs are needed. These standards should include the development and realization of strategies for sharing and reusing social-ecological ABMs, the provision of methodological guidelines for analyzing complex social-ecological ABMs such as the TRACE framework (Schmolke et al. 2010, Grimm et al. 2014) and the further propagation of using standard protocols for documenting ABMs such as the ODD+D protocol (Müller et al. 2013). Specifically for the ABM development in the field of environment-migration linkages, we propose our conceptual framework for assisting model development. Together with standards for supporting a good practice of model development, documentation, and analysis, this will help to advance agentbased modeling of environment-migration linkages and thereby foster an understanding of the environment-migration-nexus in the future.

${ }^{[1]}$ In the remainder of the article we use the term "rural migration" to refer to rural-rural as well as to rural-urban migration.

Responses to this article can be read online at: http://www.ecologyandsociety.org/issues/responses. php/10200

\section{Acknowledgments:}

We gratefully thank Matthew Berman, Behrooz HassaniMahmooei, Marco Janssen, Dominic Kniveton, Jose Manuel Magallanes, Warong Naivinit, Ali Asjad Naqvi, Deborah Rogers, Alexander Smajgl, Christopher Smith, Jing Wu, and Cheng-yi Xia for performing the cross-checks of our model categorization. JT and $\mathrm{KH}$ acknowledge funding from the German Federal Ministry of Education and Research (BMBF) within the Junior Research Group MigSoKo (01UU1606). The research reported in this paper contributes to the Programme on Ecosystem Change and Society (http://www.pecs-science.org/).

\section{LITERATURE CITED}

Ajzen, I. 1985. From intentions to actions: a theory of planned behavior. Springer, Berlin, Germany.

Ajzen, I. 1991. The theory of planned behavior. Organizational Behavior and Human Decision Processes 50(2):179-211. http://dx. doi.org/10.1016/0749-5978(91)90020-T

Berman, M., C. Nicolson, G. Kofinas, J. Tetlichi, and S. Martin. 2004. Adaptation and sustainability in a small Arctic community: results of an agent-based simulation model. Arctic 57(4):401-414. http://dx.doi.org/10.14430/arctic517

Bilsborrow, R. E. 2002. Migration, population change, and the rural environment. ECSP Report 8:69-94.

Bilsborrow, R., and S. F. Henry. 2012. The use of survey data to study migration-environment relationships in developing countries: alternative approaches to data collection. Population and Environment 34:113-141. http://dx.doi.org/10.1007/s11111-012-0177-1

Black, R., W. N, Adger, N. W. Arnell, S. Dercon, A. Geddes, and D. Thomas. 2011. The effect of environmental change on human migration. Global Environmental Change 21:S3-S11. http://dx.doi. org/10.1016/j.gloenvcha.2011.10.001

Bousquet, F., and C. Le Page. 2004. Multi-agent simulations and ecosystem management: a review. Ecological Modelling 176 (3-4):313-332. http://dx.doi.org/10.1016/j.ecolmodel.2004.01.011

Buchmann, C. M., K. Grossmann, and N. Schwarz. 2016. How agent heterogeneity, model structure and input data determine the performance of an empirical ABM: a real-world case study on residential mobility. Environmental Modelling \& Software 75:77-93. http://dx.doi.org/10.1016/j.envsoft.2015.10.005

Carr, D. 2009. Population and deforestation: why rural migration matters. Progress in Human Geography 33(3):355-378. http://dx. doi.org/10.1177/0309132508096031

Collins, J. 1986. Smallholder settlement of tropical South America: the social causes of ecological destruction. Human Organization 45(1):1-10. http://dx.doi.org/10.17730/ humo.45.1.0742x12223u09x01

de Sherbinin, A., L. K. VanWey, K. McSweeney, R. Aggarwal, A. Barbieri, S. Henry, L. M. Hunter, W. Twine, and R. Walker. 2008. Rural household demographics, livelihoods and the environment. Global Environmental Change 18:38-53. http://dx. doi.org/10.1016/j.gloenvcha.2007.05.005

Entwisle, B., G. Malanson, R. R. Rindfuss, and S. Walsh. 2008. An agent-based model of household dynamics and land use change. Journal of Land Use Science 3(1):73-93. http://dx.doi. org/10.1080/17474230802048193

Entwisle, B., N. E. Williams, A. M. Verdery, R. R. Rindfuss, S. J. Walsh, G. P. Malanson, P. J. Mucha, B. G. Frizzelle, P. M. McDaniel, X. Yao, B. W. Heumann, P. Prasartkul, Y. Sawangdee, 
and A. Jampaklay. 2016. Climate shocks and migration: an agentbased modeling approach. Population and Environment 38:47-71. http://dx.doi.org/10.1007/s11111-016-0254-y

Epstein, J., and R. Axtell. 1996. Growing artificial societies: social science from the bottom up. The Brookings Institution, Washington, D.C., USA.

Filatova, T., J. G. Polhill, and S. van Ewijk. 2016. Regime shifts in coupled socio-environmental systems: review of modelling challenges and approaches. Environmental Modelling \& Software 75:333-347. http://dx.doi.org/10.1016/j.envsoft.2015.04.003

Filatova, T., P. H. Verburg, D. C. Parker, and C. A. Stannard. 2013. Spatial agent-based models for socio-ecological systems: challenges and prospects. Environmental Modelling \& Software, 45:1-7. http://dx.doi.org/10.1016/j.envsoft.2013.03.017

Foresight. 2011. Migration and global environmental change: future challenges and opportunities. The Government Office for Science, London, UK.

Grimm, V., J. Augusiak, A. Focks, B. M. Frank, F. Gabsi, A. S. A. Johnston, C. Liu, B. T. Martin, M. Meli, V. Radchuk, P. Thorbek, and S. F. Railsback. 2014. Towards better modelling and decision support: documenting model development, testing, and analysis using TRACE. Ecological Modelling 280:129-139. http://dx.doi.org/10.1016/j.ecolmodel.2014.01.018

Groeneveld, J., B. Müller, C. M. Buchmann, G. Dressler, C. Guo, N. Hase, F. Hoffmann, F. John, C. Klassert, T. Lauf, V. Liebelt, H. Nolzen, N. Pannicke, J. Schulze, H. Weise, and N. Schwarz. 2017. Theoretical foundations of human decision-making in agent-based land use models: a review. Environmental Modelling and Software 87:39-48. http://dx.doi.org/10.1016/j.envsoft.2016.10.008

Hadzibeganovic, T., and C. Xia. 2016. Cooperation and strategy coexistence in a tag-based multi-agent system with contingent mobility. Knowledge-Based Systems 112:1-13. http://dx.doi. org/10.1016/j.knosys.2016.08.024

Hassani-Mahmooei, B., and B. W. Parris. 2012. Climate change and internal migration patterns in Bangladesh: an agent-based model. Environment and Development Economics 17:763-780. http://dx.doi.org/10.1017/S1355770X12000290

Hattle, A., K. S. Yang, and S. Zeng. 2016. Modeling the Syrian refugee crisis with agents and systems. UMAP Journal 37:195-213.

Hecht, S., A. L. Yang, B. S. Bassnett, C. Padoch, and N. L. Peluso. 2015. People in motion, forests in transition. Trends in migration, urbanization and remittances, and their effects on tropical forests. Occasional Paper 142. CIFOR, Bogor, Indonesia.

Henry, S., B. Schoumaker, and C. Beauchemin. 2004. The impact of rainfall on the first out-migration: a multi-level event-history analysis in Burkina Faso. Population \& Environment 25 (5):423-460. http://dx.doi.org/10.1023/B:POEN.0000036928.17696. e8

Huang, Q., D. C. Parker, T. Filatova, and S. Sun. 2014. A review of urban residential choice models using agent-based modeling. Environment and Planning B: Urban Analytics and City Science 41(4):661-689. http://dx.doi.org/10.1068/b120043p
Hunter, L. M., J. K. Luna, and R. M. Norton. 2015. Environmental dimensions of migration. Annual Review of Sociology 41:377-397. http://dx.doi.org/10.1146/annurevsoc-073014-112223

Janssen, M. A. 2010. Population aggregation in ancient arid environments. Ecology and Society 15(2):19. http://dx.doi. org/10.5751/ES-03376-150219

Kelly, R. A., A. J. Jakeman, O. Barreteau, M. E. Borsuk, S. ElSawah, S. H. Hamilton, H. J. Henriksen, S. Kuikka, H. R. Maier, A. E. Rizzoli, H. van Delden, and A. A.Voinov. 2013. Selecting among five common modelling approaches for integrated environmental assessment and management. Environmental Modelling \& Software 47:159-181. http://dx.doi. org/10.1016/j.envsoft.2013.05.005

Klabunde, A., and F. Willekens. 2016. Decision-making in agentbased models of migration: state of the art and challenges. European Journal of Population 32:73-97. http://dx.doi. org/10.1007/s10680-015-9362-0

Kniveton, D. R., C. D. Smith, and R. Black. 2012. Emerging migration flows in a changing climate in dryland Africa. Nature Climate Change 2:444-447. http://dx.doi.org/10.1038/nclimate1447

Kniveton, D. R., C. D. Smith, and S. Wood. 2011. Agent-based model simulations of future changes in migration flows for Burkina Faso. Global Environmental Change 21:S34-S40. http:// dx.doi.org/10.1016/j.gloenvcha.2011.09.006

Krol, M. S., and A. Bronstert. 2007. Regional integrated modelling of climate change impacts on natural resources and resource usage in semi-arid Northeast Brazil. Environmental Modelling \& Software 22:259-268. http://dx.doi.org/10.1016/j. envsoft.2005.07.022

Lambin, E. F., and P. Meyfroidt. 2011. Global land use change, economic globalization, and the looming land scarcity. Proceedings of the National Academy of Sciences 108:3465-3472. http://dx.doi.org/10.1073/pnas.1100480108

Lee, J.-S., T. Filatova, A. Ligmann-Zielinska, B. HassaniMahmooei, F. Stonedahl, I. Lorscheid, A. A. Voinov, G. Polhill, Z. Sung, and D. C. Parker. 2015. The complexities of agent-based modeling output analysis. Journal of Artificial Societies and Social Simulation 18(4):4. http://dx.doi.org/10.18564/jasss.2897

Magallanes, J. M., A. Burger, and C. Cioffi-Revilla. 2014. Understanding migration induced by climate change in the Central Andes of Peru via agent-based computational modeling. In J. Sichman, E. MacKerrow, F. Squazzoni, and T. Terano, editors. Proceedings of the 5th World Congress on Social Simulation. Sao Paolo, Brazil.

Martin, R., and M. Schlüter. 2015. Combining system dynamics and agent-based modeling to analyze social-ecological interactions - an example from modeling restoration of a shallow lake. Frontiers in Environmental Science 3:66. http://dx.doi. org/10.3389/fenvs.2015.00066

Matthews, R. B., N. G. Gilbert, A. Roach, J. G. Polhill, and N. M. Gotts. 2007. Agent-based land-use models: a review of applications. Landscape Ecology 22(10):1447-1459. http://dx.doi. org/10.1007/s10980-007-9135-1 
McLeman, R. A. 2013a. Climate and human migration: past experiences, future challenges. Cambridge University Press, Cambridge, UK. http://dx.doi.org/10.1017/CBO9781139136938

McLeman, R. 2013b. Developments in modelling of climate change-related migration. Climatic Change 117:599-611. http:// dx.doi.org/10.1007/s10584-012-0578-2

McLeman, R. 2017. Migration and land degradation: recent experiences and future trends. Global Land Outlook Working Paper. United Nations Convention to Combat Desertification, Paris, France.

Mena, C. F., S. J. Walsh, B. G. Frizzelle, Y. Xiaozheng, and G. P. Malanson. 2011. Land use change on household farms in the Ecuadorian Amazon: design and implementation of an agentbased model. Applied Geography 31(1):210-222. http://dx.doi. org/10.1016/j.apgeog.2010.04.005

Morrissey, J. W. 2013. Understanding the relationship between environmental change and migration: the development of an effects framework based on the case of northern Ethiopia. Global Environmental Change 23:1501-1510. http://dx.doi.org/10.1016/j. gloenvcha.2013.07.021

Müller, B., S. Balbi, C. M. Buchmann, L. De Sousa, G. Dressler, J. Groeneveld, C. J. Klassert, Q. B. Le, J. D. A. Millington, H. Nolzen, D. C. Parker, J. G. Polhill, M. Schlüter, J. Schulze, N. Schwarz, Z. Sun, P. Taillandier, and H. Weise. 2014. Standardised and transparent model descriptions for agent-based models: current status and prospects. Environmental Modelling \& Software 55:156-163. http://dx.doi.org/10.1016/j.envsoft.2014.01.029

Müller, B., F. Bohn, G. Dreßler, J. Groeneveld, C. Klassert, R. Martin, M. Schlüter, J. Schulze, H. Weise, and N. Schwarz. 2013. Describing human decisions in agent-based models-ODD $+\mathrm{d}$, an extension of the ODD protocol. Environmental Modelling \& Software 48:37-48. http://dx.doi.org/10.1016/j.envsoft.2013.06.003

Naivinit, W., C. Le Page, G. Trébuil, and N. Gajaseni. 2010. Participatory agent-based modeling and simulation of rice production and labor migrations in northeast Thailand. Environmental Modelling \& Software 25(11):1345-1358. http://dx. doi.org/10.1016/j.envsoft.2010.01.012

Naqvi, A. A., and M. Rehm. 2014. A multi-agent model of a low income economy: simulating the distributional effects of natural disasters. Journal of Economic Interaction and Coordination 9 (2):275-309. http://dx.doi.org/10.1007/s11403-014-0137-1

Neumann, K., and F. Hermans. 2017. What drives human migration in Sahelian countries? A meta-analysis. Population, Space and Place 23:e1962. http://dx.doi.org/10.1002/psp.1962

Neumann, K., and H. Hilderink. 2015. Opportunities and challenges for investigating the environment-migration nexus. Human Ecology 43:309-322. http://dx.doi.org/10.1007/s10745-015-9733-5

Neumann-Hermans, K., K. Gerstner, I. Geijzendorffer, M. Herold, R. Seppelt, and S. Wunder. 2016. Why do forest products become less available? A pan-tropical comparison of drivers of forest-resource degradation. Environmental Research Letters 11 (12):125010. http://dx.doi.org/10.1088/1748-9326/11/12/125010

Parker, D. C., A. Hessl, and S. C. Davis. 2008. Complexity, landuse modeling, and the human dimension: fundamental challenges for mapping unknown outcome spaces. Geoforum 39(2):789-804. http://dx.doi.org/10.1016/j.geoforum.2007.05.005

Parker, D. C., S. M. Manson, M. A. Janssen, M. J. Hoffmann, and P. Deadman. 2003. Multi-agent systems for the simulation of land-use and land-cover change: a review. Annals of the Association of American Geographers 93:314-337. http://dx.doi. org/10.1111/1467-8306.9302004

Polhill, J. G., T. Filatova, M. Schlüter, and A. Voinov. 2016. Modelling systemic change in coupled socio-environmental systems. Environmental Modelling \& Software 75:318-332. http:// dx.doi.org/10.1016/j.envsoft.2015.10.017

Preston, D. 1998. Post-peasant capitalist grazers: the 21st century in southern Bolivia. Mountain Research and Development 18 (2):151-158. http://dx.doi.org/10.2307/3673970

Rademacher-Schulz, C., B. Schraven, and E. D. Mahama. 2014. Time matters: shifting seasonal migration in northern Ghana in response to rainfall variability and food insecurity. Climate and Development 6(1):46-52. http://dx.doi.org/10.1080/17565529.2013.830955

Rigaud, K. K., A. de Sherbinin, B. Jones, J. Bergmann, V. Clement, K. Ober, J. Schewe, S. Adamo, B. McCusker, S. Heuser, and A. Midgley. 2018. Groundswell: preparing for internal climate migration. World Bank, Washington, D.C., USA. http://dx.doi. org/10.1596/29461

Rogers, D. S., O. Deshpande, and M. W. Feldman. 2011. The spread of inequality. PLoS ONE 6(9):e24683. http://dx.doi. org/10.1371/journal.pone.0024683

Schlüter, M., R. R. J. McAllister, R. Arlinghaus, N. Bunnefeld, K. Eisenack, F. Hölker, E. J. Milner-Gulland, B. Müller, E. Nicholson, M. Quaas, and M. Stöven. 2012. New horizons for managing the environment: a review of coupled social-ecological systems modeling. Natural Resource Modeling 25(1):219-272. http://dx.doi.org/10.1111/j.1939-7445.2011.00108.x

Schmolke, A., P. Thorbek, D. L. DeAngelis, and V. Grimm. 2010. Ecological models supporting environmental decision making: a strategy for the future. Trends in Ecology \& Evolution 25 (8):479-486. http://dx.doi.org/10.1016/j.tree.2010.05.001

Schulze, J., B. Müller, J. Groeneveld, and V. Grimm. 2017. Agentbased modelling of social-ecological systems: achievements, challenges, and a way forward. Journal of Artificial Societies and Social Simulation 20(2):8. http://dx.doi.org/10.18564/jasss.3423

Smajgl, A., and E. Bohensky. 2013. Behaviour and space in agentbased modelling: poverty patterns in East Kalimantan, Indonesia. Environmental Modelling \& Software 45:8-14. http:// dx.doi.org/10.1016/j.envsoft.2011.10.014

Smajgl, A., D. G. Brown, D. Valbuena, and M. G. A. Huigen. 2011. Empirical characterisation of agent behaviours in socioecological systems. Environmental Modelling \& Software 26 (7):837-844. http://dx.doi.org/10.1016/j.envsoft.2011.02.011

Smajgl, A., G. Carlin, A. House, J. Butler, E. Bohensky, A. S. Kurnia, C. Sugiyanto, and M. Hodgen. 2009. Design document for agent-based model SimPaSI Jawa Tengah. Simulating pathways to sustainability in Indonesia. CSIRO, Townsville, Australia.

Smajgl, A., S. Egan, M. Kirby, M. Mainuddin, J. Ward, and F. Kroon. 2013. The Mekong Region simulation (Mersim) model - 
design document. CSIRO Climate Adaptation Flagship, Townsville, Australia.

Smajgl, A., J. Xu, S. Egan, Z.-F. Yi, J. Ward, and Y. Su. $2015 a$. Assessing the effectiveness of payments for ecosystem services for diversifying rubber in Yunnan, China. Environmental Modelling \& Software 69:187-195. http://dx.doi.org/10.1016/j.envsoft.2015.03.014

Smajgl, A., J. R. Ward, T. Foran, J. Dore, and S. Larson. $2015 b$. Visions, beliefs, and transformation: exploring cross-sector and transboundary dynamics in the wider Mekong region. Ecology and Society 20(2):15. http://dx.doi.org/10.5751/ES-07421-200215

Smith, C. D. 2014. Modelling migration futures: development and testing of the rainfalls agent-based migration model - Tanzania. Climate and Development 6(1):77-91. http://dx.doi. org/10.1080/17565529.2013.872593

Suleimenova, D., D. Bell, and D. Groen. 2017. A generalized simulation development approach for predicting refugee destinations. Scientific Reports 7:13377. http://dx.doi.org/10.1038/ s41598-017-13828-9

Sun, Z., I. Lorscheid, J. D. Millington, S. Lauf, N. R. Magliocca, J. Groeneveld, S. Balbi, H. Nolzen, B. Müller, J. Schulze, and C. M. Buchmann. 2016. Simple or complicated agent-based models? A complicated issue. Environmental Modelling \& Software 86:56-67. http://dx.doi.org/10.1016/j.envsoft.2016.09.006

United Nations 2013. International migration report 2013. Department of Economic and Social Affairs, Population Division, New York City, New York, USA.

Walsh, S. J., G. P. Malanson, B. Entwisle, R. R. Rindfuss, P. J. Mucha, B. W. Heumann, P. M. McDaniel, B. G. Frizzelle, A. M. Verdery, N. E. Williams, X. Yao, and D. Ding. 2013. Design of an agent-based model to examine population - environment interactions in Nang Rong District, Thailand. Applied Geography 39:183-198. http://dx.doi.org/10.1016/j.apgeog.2012.12.010

Willekens, F., J. Bijak, A. Klabunde, and A. Prskawetz. 2017. The science of choice: an introduction. Population Studies 71 (sup1):1-13. http://dx.doi.org/10.1080/00324728.2017.1376921

Wu, J., R. Mohamed, and Z. Wang. 2011. Agent-based simulation of the spatial evolution of the historical population in China. Journal of Historical Geography 37:12-21. http://dx.doi. org/10.1016/j.jhg.2010.03.006

Zimmerer, K. S. 2004. Cultural ecology: placing households in human-environment studies - the cases of tropical forest transitions and agrobiodiversity change. Progress in Human Geography 28:795-806. http://dx.doi.org/10.1191/0309132504ph520pr 
Appendix 1. Classifications of reviewed models

This document is listed as online resource for the publication:

Title: Agent-based modeling of environment-migration linkages: a review

Journal name: Ecology \& Society

This document contains the classifications of the reviewed agent-based models. This includes the diagrams drafted based on the conceptual framework as well as the filled out standardized protocols for each of the reviewed agent-based models. 
Berman et al. 2004

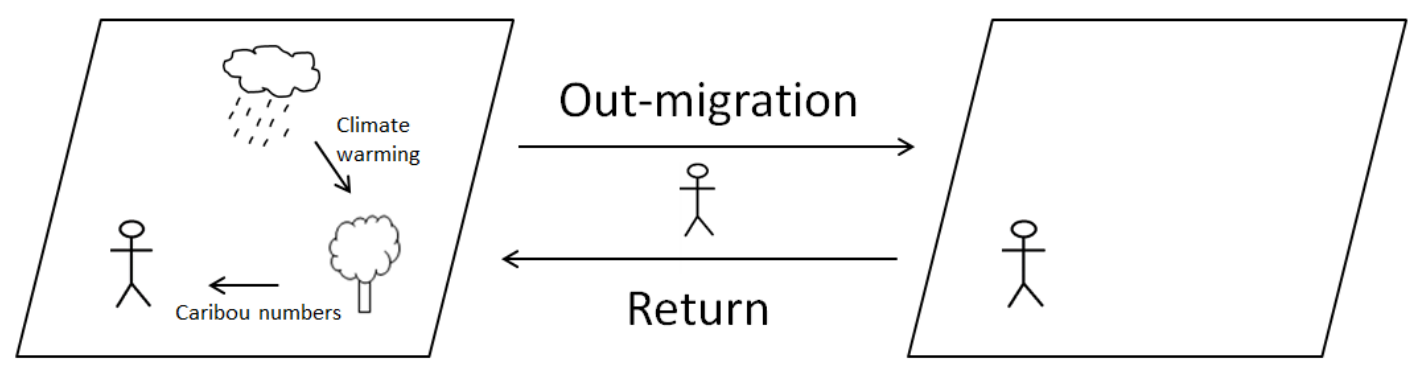

Fig. A1.1 Diagram drafted for the ABM described by Berman et al. (2004)

Table A1.1 Standardized protocol for the ABM described by Berman et al. (2004)

\begin{tabular}{|c|c|c|c|c|c|}
\hline \multicolumn{6}{|l|}{ General } \\
\hline \multicolumn{6}{|c|}{$\begin{array}{l}\text { Reference(s): } \\
\text { Berman, M., C. Nicolson, G. Kofinas, J. Tetlichi, and S. Martin. 2004. Adaptation and sustainability in } \\
\text { a small Arctic community: results of an agent-based simulation model. Arctic 57(4):401-414. }\end{array}$} \\
\hline \multicolumn{4}{|c|}{$\begin{array}{ll}\text { Purpose of the study } & \\
\text { 1. System understanding } & \text { 5. Theory development } \\
\text { 2. Prediction (quantitative) } & \text { 6. Hypothesis testing } \\
\text { 3. Management or decision } & \text { 7. Not clearly stated } \\
\begin{array}{l}\text { support } \\
\text { 4. Communication (participatory }\end{array} & \text { multiple criteria possible } \\
\text { approaches) } & \end{array}$} & \multicolumn{2}{|c|}{$\begin{array}{l}\text { Case study } \\
{[\text { Y]es/[N]o/[C]ontext-specific }} \\
\text { conceptual model (for most of } \\
\text { model processes; only hunting } \\
\text { and harvesting are based on } \\
\text { geographic data) } \\
\text { Western Arctic Canadian } \\
\text { community of Old Crow, } \\
\text { Yukon }\end{array}$} \\
\hline \multicolumn{3}{|c|}{$\begin{array}{l}\text { Spatial scale } \\
\text { Based on the distance a hunter can travel in one } \\
\text { day }\end{array}$} & \multicolumn{3}{|c|}{$\begin{array}{l}\text { Temporal scale } \\
40 \text { years with } 5 \text { seasons per year (hunting takes } \\
\text { place } 5 \text { times a year, migration once every } 5 \text { years) }\end{array}$} \\
\hline \multicolumn{6}{|l|}{ Migration process } \\
\hline \multicolumn{3}{|l|}{$\begin{array}{l}\text { Migration flow } \\
\text { 1. } \text { Out-migration } \\
\text { 2. } \\
\text { 3. } \\
\text { Indirect return } \\
\text { Indect return }\end{array}$} & \multicolumn{2}{|c|}{$\begin{array}{l}\text { Agents know situation } \\
\text { at destination } \\
1 . \quad \text { Yes } \\
\text { 2. No }\end{array}$} & $\begin{array}{ll}\text { Duration } \\
\text { 1. Seasonal } \\
\text { 2. Permanent } \\
\text { 3. } \text { Both }\end{array}$ \\
\hline \multicolumn{6}{|l|}{ Migration decision } \\
\hline $\begin{array}{l}\text { Number of } \\
\text { environmental } \\
\text { influence factors: } 2\end{array}$ & \multicolumn{2}{|c|}{$\begin{array}{l}\text { Which factor: } \\
\text { Climate warming, } \\
\text { caribou numbers }\end{array}$} & \multicolumn{2}{|c|}{\begin{tabular}{l}
\multicolumn{2}{l}{ Type } \\
1. Abiotic (climate \\
warming) \\
2. $\begin{array}{l}\text { Biotic (caribou } \\
\text { numbers) }\end{array}$
\end{tabular}} & $\begin{array}{ll}\text { Direct/indirect } \\
\text { 1. } & \text { Direct } \\
\text { 2. } & \text { Indirect (via } \\
& \text { hunting success) }\end{array}$ \\
\hline
\end{tabular}




\begin{tabular}{|c|c|c|c|}
\hline $\begin{array}{l}\text { Other influence } \\
\text { factors } \\
\text { 1. Economic } \\
\text { 2. Social } \\
\text { 3. Both }\end{array}$ & $\begin{array}{l}\text { Which factor: } \\
\text { Earnings, household } \\
\text { type, age, education, } \\
\text { sex }\end{array}$ & $\begin{array}{l}\text { Social network } \\
\text { 1. Yes } \\
\text { 2. No }\end{array}$ & $\begin{array}{l}\text { How: } \\
\text { Sharing of hunting gear } \\
\text { and harvest sharing } \\
\text { occur throughout the } \\
\text { community }\end{array}$ \\
\hline
\end{tabular}

\section{Methodology}

1. Probability function

2. Decision theory

3. Heuristic

4. Optimization

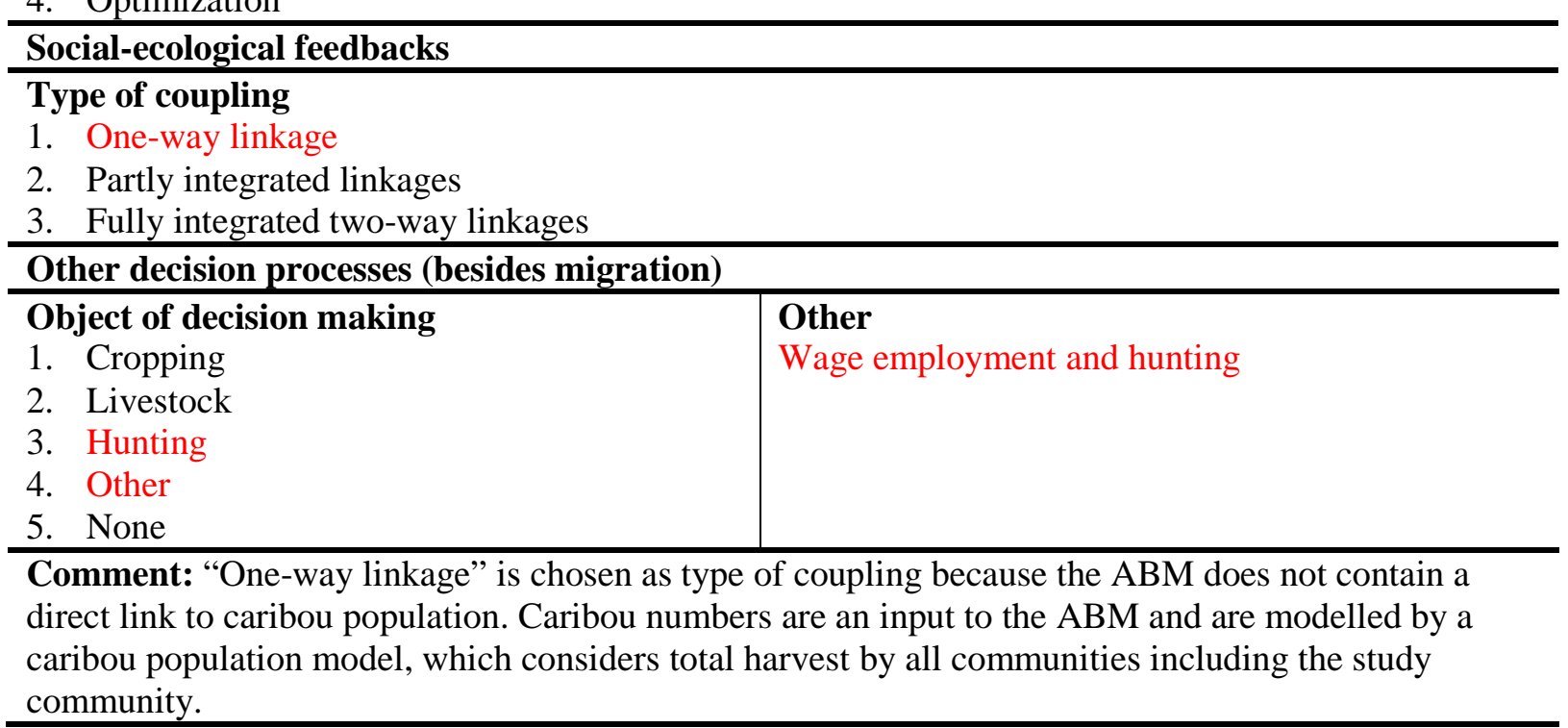


Hadzibeganovic \& Xia 2016

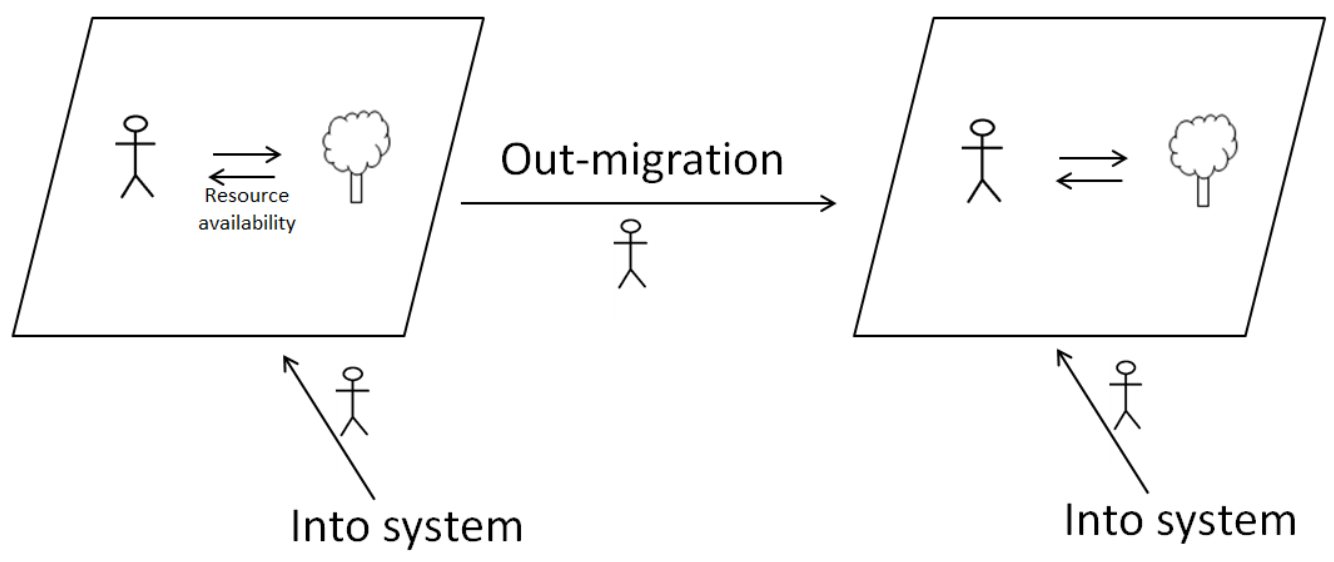

Fig. A1.2 Diagram drafted for the ABM described by Hadzibeganovic \& Xia (2016); the model includes two types of migration decision (, reproduction-based “ and „payoff-based") of which one is with knowledge of the destination system (i.e. emptiness of a node) and one is not; the case with knowledge of the destination system is illustrated here

Table A1.2 Standardized protocol for the ABM described by Hadzibeganovic \& Xia (2016)

\begin{tabular}{|c|c|c|c|c|c|}
\hline \multicolumn{6}{|l|}{ General } \\
\hline \multicolumn{6}{|c|}{$\begin{array}{l}\text { Reference(s): } \\
\text { Hadzibeganovic, T., and C. Xia. 2016. Cooperation and strategy coexistence in a tag-based multi- } \\
\text { agent system with contingent mobility. Knowledge-Based Systems 112:1-13. }\end{array}$} \\
\hline \multicolumn{4}{|c|}{$\begin{array}{l}\text { Purpose of the study } \\
\text { 1. System understanding } \\
\text { 2. Prediction (quantitative) } \\
\text { 3. Management or decision } \\
\text { support } \\
\text { 4. Communication (participatory } \\
\text { approaches) }\end{array}$} & \multicolumn{2}{|c|}{$\begin{array}{l}\text { Case study } \\
{[\mathrm{Y}] \mathrm{es} /[\mathrm{N}] \mathrm{o} /[\mathrm{C}] \text { ontext-specific }} \\
\text { conceptual model }\end{array}$} \\
\hline \multicolumn{3}{|c|}{$\begin{array}{l}\text { Spatial scale } \\
\text { System size } 10000 \text { nodes }\end{array}$} & \multicolumn{3}{|c|}{$\begin{array}{l}\text { Temporal scale } \\
\text { Model runs until equilibrium was reached; mostly } \\
\text { after } 5000 \text { steps }\end{array}$} \\
\hline \multicolumn{6}{|l|}{ Migration process } \\
\hline \multicolumn{3}{|l|}{ 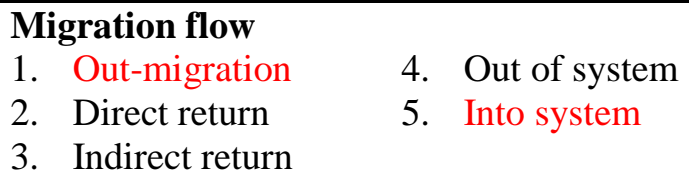 } & \multicolumn{2}{|c|}{$\begin{array}{l}\text { Agents know situation } \\
\text { at destination } \\
\text { 1. Yes } \\
\text { 2. No }\end{array}$} & $\begin{array}{l}\text { Duration } \\
\text { 1. Seasonal } \\
\text { 2. Permanent } \\
\text { 3. } \text { Both }\end{array}$ \\
\hline
\end{tabular}




\section{Migration decision}

\begin{tabular}{|c|c|c|c|}
\hline $\begin{array}{l}\text { Number of } \\
\text { environmental } \\
\text { influence factors: } 1\end{array}$ & $\begin{array}{l}\text { Which factor: } \\
\text { Resource availability } \\
\text { (food source) }\end{array}$ & $\begin{array}{l}\text { Type } \\
\text { 1. Abiotic } \\
\text { 2. Biotic }\end{array}$ & $\begin{array}{l}\text { Direct/indirect } \\
\text { 1. } \quad \text { Direct } \\
\text { 2. } \text { Indirect }\end{array}$ \\
\hline $\begin{array}{l}\text { Other influence } \\
\text { factors } \\
\text { 1. Economic } \\
\text { 2. Social } \\
\text { 3. } \text { Both }\end{array}$ & $\begin{array}{l}\text { Which factor: } \\
\text { Average fitness of } \\
\text { neighbors }\end{array}$ & $\begin{array}{l}\text { Social network } \\
\text { 1. Yes } \\
\text { 2. No }\end{array}$ & How: \\
\hline
\end{tabular}

\section{Methodology}

1. Probability function

2. Decision theory

3. Heuristic

4. Optimization

Social-ecological feedbacks

Type of coupling

1. One-way linkage

2. Partly integrated linkages

3. Fully integrated two-way linkages

\begin{tabular}{l|l}
\hline \multicolumn{2}{l}{ Other decision processes (besides migration) } \\
\hline Object of decision making & Other \\
1. $\quad$ Cropping & Prisoner's dilemma games \\
2. Livestock & \\
3. Hunting & \\
4. Other & \\
5. None & \\
\hline
\end{tabular}




\section{Hassani-Mahmooei \& Parris 2012}

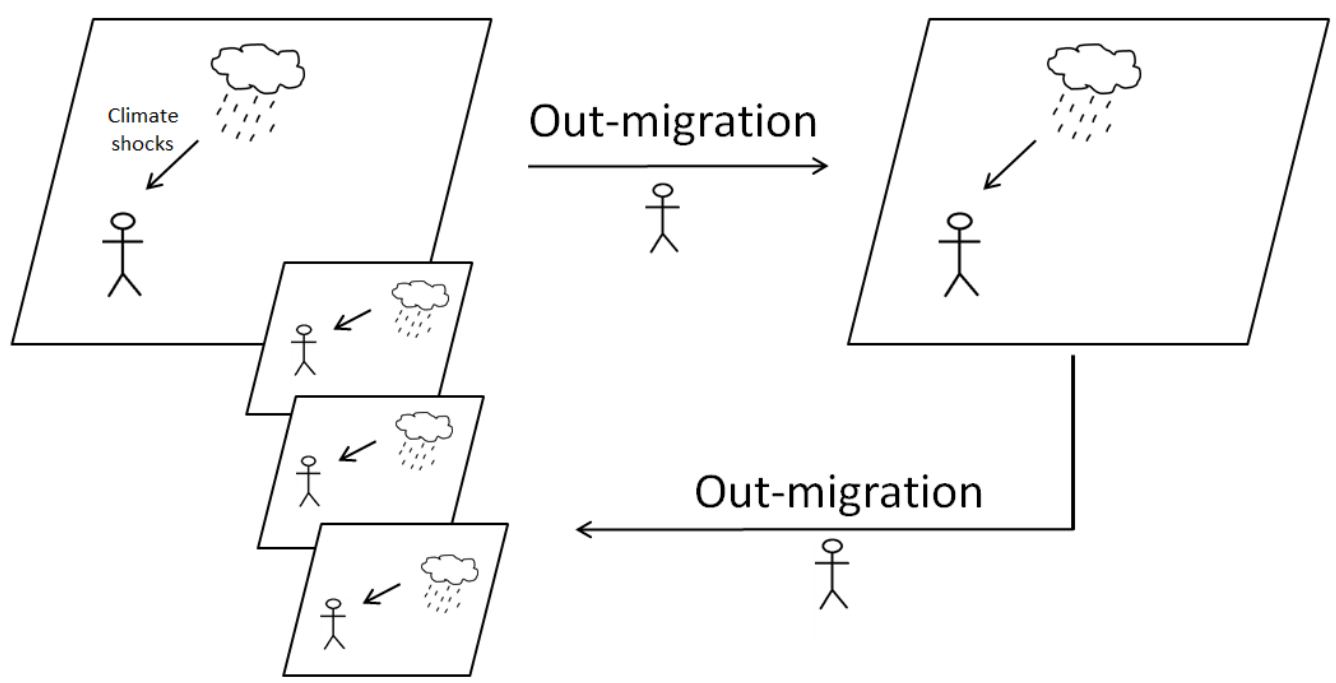

Fig. A1.3 Diagram drafted for the ABM described by Hassani-Mahmooei \& Parris (2012); agents do not make explicit return decisions, but migrate from region to region and can thereby visit a region again at some point in the future

Table A1.3 Standardized protocol for the ABM described by Hassani-Mahmooei \& Parris (2012)

\section{General}

Reference(s):

Hassani-Mahmooei, B., and B. W. Parris. 2012. Climate change and internal migration patterns in Bangladesh: an agent-based model. Environment and Development Economics 17:763-780.

\section{Purpose of the study}

1. System understanding

2. Prediction (quantitative)

3. Management or decision support

4. Communication (participatory multiple criteria possible approaches)
5. Theory development

6. Hypothesis testing

7. Not clearly stated
Case study

$[\mathrm{Y}] \mathrm{es} /[\mathrm{N}] \mathrm{o} /[\mathrm{C}]$ ontext-specific conceptual model

Bangladesh

\section{Spatial scale}

Bangladesh divided in 64 districts

\section{Migration process}

\section{Migration flow}

1. Out-migration

2. Direct return

5. Out of system

3. Indirect return

6. Into system
Temporal scale

50 years in monthly time steps

\begin{tabular}{l|ll}
\hline Agents know situation & \multicolumn{2}{|l}{ Duration } \\
at destination & 1. & Seasonal \\
1. Yes & 2. & Permanent \\
$2 . \quad$ No & 3. & Both
\end{tabular}




\begin{tabular}{|c|c|c|c|}
\hline \multicolumn{4}{|l|}{ Migration decision } \\
\hline $\begin{array}{l}\text { Number of } \\
\text { environmental } \\
\text { influence factors: } 4 \\
\text { combined in one }\end{array}$ & $\begin{array}{l}\text { Which factor: } \\
\text { Climate shock } \\
\text { represented by } \\
\text { combination of } \\
\text { droughts, floods, } \\
\text { cyclones and sea level } \\
\text { rise }\end{array}$ & \begin{tabular}{ll}
\multicolumn{2}{l}{ Type } \\
1. Abiotic \\
2. Biotic
\end{tabular} & $\begin{array}{ll}\text { Direct/indirect } \\
\text { 1. } & \text { Direct } \\
\text { 2. } & \text { Indirect }\end{array}$ \\
\hline $\begin{array}{l}\text { Other influence } \\
\text { factors } \\
\text { 1. Economic } \\
\text { 2. Social } \\
\text { 3. Both }\end{array}$ & $\begin{array}{l}\text { Which factor: } \\
\text { Intervening factors: } \\
\text { household ownership, } \\
\text { land ownership, } \\
\text { employment } \\
\text { Pull factors: } \\
\text { socioeconomic } \\
\text { conditions of the } \\
\text { potential destinations } \\
\text { (economic variable, } \\
\text { education, ethnic } \\
\text { composition, } \\
\text { infrastructure, health, } \\
\text { mutual distance) } \\
\text { Push factors: poverty } \\
\text { level, local } \\
\text { government } \\
\text { development } \\
\text { expenditures and } \\
\text { unemployment rate }\end{array}$ & $\begin{array}{l}\text { Social network } \\
\text { 1. Yes } \\
\text { 2. No }\end{array}$ & How: \\
\hline $\begin{array}{ll}\text { Methodology } \\
\text { 1. } \\
\text { 2. } \text { Probability functi } \\
\text { 3. Heuristic } \\
\text { 4. } & \text { Optimization } \\
\end{array}$ & & & \\
\hline \multicolumn{4}{|c|}{ Social-ecological feedbacks } \\
\hline 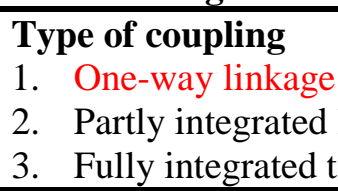 & $\begin{array}{l}\text { ages } \\
\text { way linkages }\end{array}$ & & \\
\hline \multicolumn{4}{|c|}{ Other decision processes (besides migration) } \\
\hline $\begin{array}{ll}\text { Object of decision m } \\
\text { 1. } & \text { Cropping } \\
\text { 2. } & \text { Livestock } \\
\text { 3. } & \text { Hunting } \\
\text { 4. } & \text { Other } \\
\text { 5. } & \text { None }\end{array}$ & & Other & \\
\hline
\end{tabular}




\section{Janssen 2010}

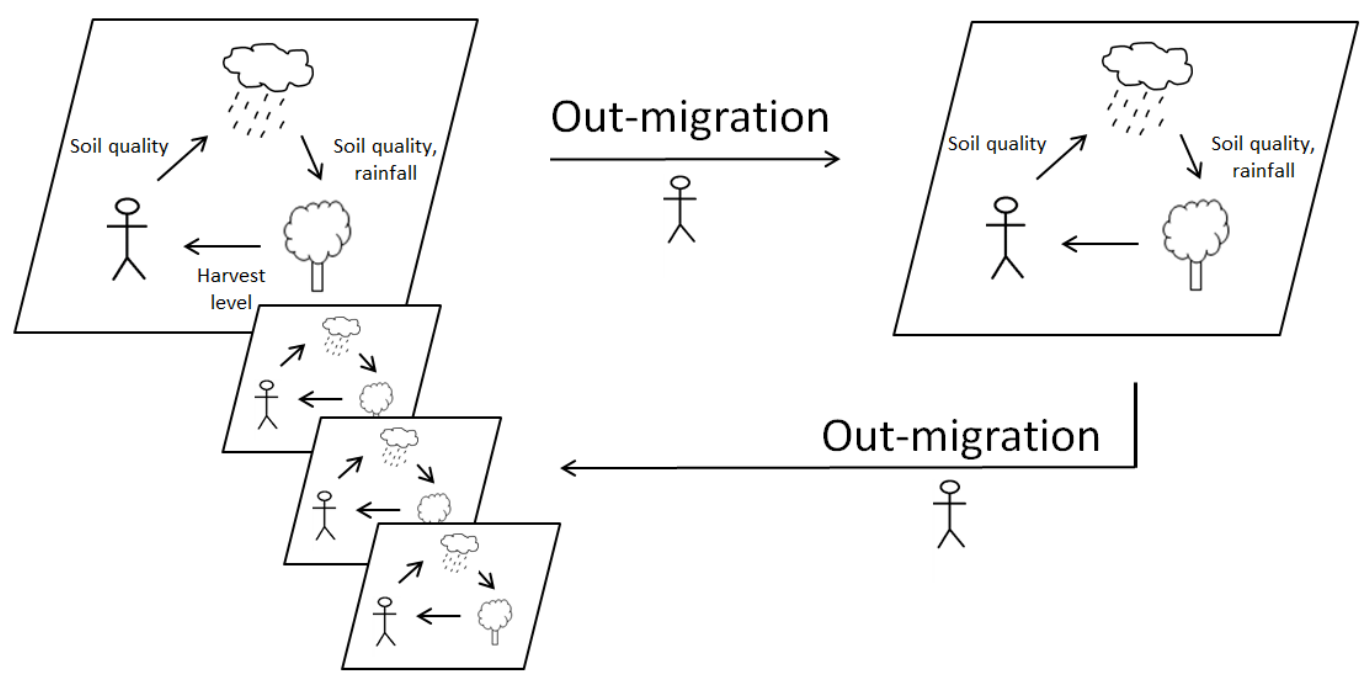

Fig. A1.4 Diagram drafted for the ABM described by Janssen (2010); agents do not make explicit return decisions, but migrate from region to region and can thereby visit a region again at some point in the future

Table A1.4 Standardized protocol for the ABM described by Janssen (2010)

\begin{tabular}{|c|c|c|c|c|c|}
\hline \multicolumn{6}{|l|}{ General } \\
\hline \multicolumn{6}{|c|}{$\begin{array}{l}\text { Reference(s): } \\
\text { Janssen, M. A. 2010. Population aggregation in ancient arid environments. Ecology and Society } \\
\text { 15(2):19. }\end{array}$} \\
\hline \multicolumn{4}{|c|}{$\begin{array}{l}\text { Purpose of the study } \\
\text { 1. System understanding } \\
\text { 2. Prediction (quantitative) } \\
\text { 3. Management or decision } \\
\text { support } \\
\text { 4. Communication (participatory } \\
\text { approaches) }\end{array}$} & \multicolumn{2}{|c|}{$\begin{array}{l}\text { Case study } \\
{[\mathrm{Y}] \mathrm{es} /[\mathrm{N}] \mathrm{o} /[\mathrm{C}] \text { ontext-specific }} \\
\text { conceptual model } \\
\text { American Southwest }\end{array}$} \\
\hline \multicolumn{3}{|c|}{$\begin{array}{l}\text { Spatial scale } \\
20 * 20 \text { cells with } 10 * 10 \mathrm{~km}\end{array}$} & \multicolumn{3}{|c|}{\begin{tabular}{|l|} 
Temporal scale \\
Yearly time steps for 10000 years
\end{tabular}} \\
\hline \multicolumn{6}{|l|}{ Migration process } \\
\hline \multicolumn{3}{|l|}{$\begin{array}{l}\text { Migration flow } \\
\text { 1. } \text { Out-migration } \\
\text { 2. Direct return } \\
\text { 3. } \\
\text { Indirect return }\end{array}$} & \multicolumn{2}{|c|}{$\begin{array}{l}\text { Agents know situation } \\
\text { at destination } \\
\text { 1. Yes } \\
\text { 2. No }\end{array}$} & $\begin{array}{l}\text { Duration } \\
\text { 1. Seasonal } \\
\text { 2. Permanent } \\
\text { 3. } \text { Both }\end{array}$ \\
\hline
\end{tabular}




\section{Migration decision}

\begin{tabular}{|c|c|c|c|}
\hline $\begin{array}{l}\text { Number of } \\
\text { environmental } \\
\text { influence factors: } 3\end{array}$ & $\begin{array}{l}\text { Which factor: } \\
\text { Rainfall, soil quality } \\
\text { depletion and } \\
\text { recovery, harvest } \\
\text { level }\end{array}$ & $\begin{array}{l}\text { Type } \\
\text { 1. Abiotic (rain) } \\
\text { 2. Biotic (soil quality, } \\
\text { harvest) }\end{array}$ & \begin{tabular}{ll}
\multicolumn{2}{l}{ Direct/indirect } \\
1. & Direct (Harvest) \\
2. & Indirect (Soil \\
& quality, rainfall)
\end{tabular} \\
\hline $\begin{array}{l}\text { Other influence } \\
\text { factors } \\
\text { 1. Economic } \\
\text { 2. Social } \\
\text { 3. Both }\end{array}$ & $\begin{array}{l}\text { Which factor: } \\
\text { Population level \& } \\
\text { experience \& } \\
\text { required proportion of } \\
\text { productivity in } \\
\text { current cell (to } \\
\text { consider moving } \\
\text { costs) \& storage }\end{array}$ & $\begin{array}{l}\text { Social network } \\
1 \text {. Yes } \\
\text { 2. No }\end{array}$ & How: \\
\hline
\end{tabular}

\section{Methodology}

1. Probability function

2. Decision theory

3. Heuristic

4. Optimization

Social-ecological feedbacks

Type of coupling

1. One-way linkage

2. Partly integrated linkages

3. Fully integrated two-way linkages

\begin{tabular}{l|l}
\hline \multicolumn{2}{l}{ Other decision processes (besides migration) } \\
\hline Object of decision making & Other \\
1. Cropping & Sharing of food and exchange between settlements \\
2. Livestock & \\
3. Hunting & \\
4. Other & \\
5. None & \\
\hline
\end{tabular}




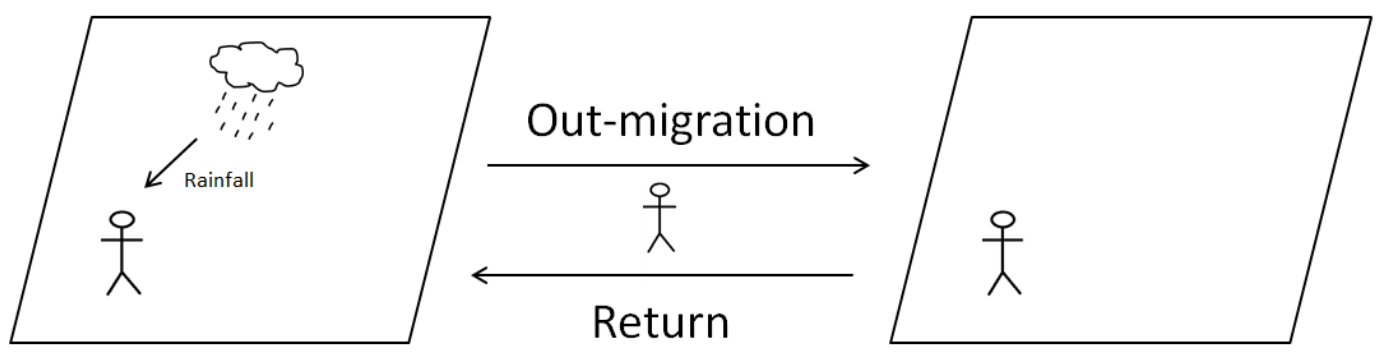

Fig. A1.5 Diagram drafted for the ABM described by Kniveton et al. (2011; 2012); the destination system is also influenced by rainfall, but as the return decision is not influenced by rainfall it is not depicted visually in the destination system

Table A1.5 Standardized protocol for the ABM described by Kniveton et al. $(2011 ; 2012)$

\section{General}

\section{Reference(s):}

Kniveton, D. R., C. D. Smith, and R. Black. 2012. Emerging migration flows in a changing climate in dryland Africa. Nature Climate Change 2:444-447.

Kniveton, D. R., C. D. Smith, and S. Wood. 2011. Agent-based model simulations of future changes in migration flows for Burkina Faso. Global Environmental Change 21:S34-S40.

\section{Purpose of the study}

1. System understanding

2. Prediction (quantitative)

3. Management or decision support

4. Communication (participatory multiple criteria possible approaches)
5. Theory development

6. Hypothesis testing

7. Not clearly stated
Case study

$[\mathrm{Y}] \mathrm{es} /[\mathrm{N}] \mathrm{o} /[\mathrm{C}]$ ontext-specific conceptual model

Burkina Faso

\section{Spatial scale}

Burkina Faso divided into 5 regions

\section{Migration process}

\section{Migration flow}

1. Out-migration

2. Direct return

3. Indirect return
5. Out of system

6. Into system
Temporal scale

Validation: 1970 to 2000, scenarios: to 2060.

Daily time steps, but birth, ageing, marriage and death events on monthly basis, migration yearly decision

\begin{tabular}{|c|c|}
\hline $\begin{array}{l}\text { Agents know situation } \\
\text { at destination } \\
\text { 1. Yes } \\
\text { 2. No }\end{array}$ & \begin{tabular}{ll}
\multicolumn{2}{l}{ Duration } \\
1. & Seasonal \\
2. & Permanent \\
3. & Both
\end{tabular} \\
\hline
\end{tabular}




\begin{tabular}{|c|c|c|c|}
\hline \multicolumn{4}{|l|}{ Migration decision } \\
\hline $\begin{array}{l}\text { Number of } \\
\text { environmental } \\
\text { influence factors: } 1\end{array}$ & $\begin{array}{l}\text { Which factor: } \\
\text { Rainfall }\end{array}$ & $\begin{array}{l}\text { Type } \\
\text { 1. Abiotic } \\
\text { 2. } \text { Biotic }\end{array}$ & $\begin{array}{l}\text { Direct/indirect } \\
\text { 1. Direct } \\
\text { 2. Indirect }\end{array}$ \\
\hline $\begin{array}{l}\text { Other influence } \\
\text { factors } \\
\text { 1. Economic } \\
\text { 2. Social } \\
\text { 3. Both }\end{array}$ & $\begin{array}{l}\text { Which factor: } \\
\text { age, gender, marital } \\
\text { status, assets, } \\
\text { experience, behavior } \\
\text { of peers }\end{array}$ & $\begin{array}{l}\text { Social network } \\
\text { 1. Yes } \\
\text { 2. No }\end{array}$ & $\begin{array}{l}\text { How: } \\
\text { Fixed network for } \\
\text { information exchange; } \\
\text { each agent randomly } \\
\text { linked to } 50 \text { others at } \\
\text { initialization }\end{array}$ \\
\hline
\end{tabular}

\section{Methodology}

1. Probability function

2. Decision theory

3. Heuristic

4. Optimization

\begin{tabular}{l|l}
\multicolumn{1}{l}{ Social-ecological feedbacks } \\
\multicolumn{2}{l}{ Type of coupling } \\
1. One-way linkage \\
2. Partly integrated linkages \\
3. Fully integrated two-way linkages \\
\hline \multicolumn{2}{l}{ Other decision processes (besides migration) } \\
\hline \multicolumn{1}{l}{ Object of decision making } & Other \\
1. Cropping & \\
2. Livestock & \\
3. Hunting & \\
4. Other & \\
5. None & \\
\hline
\end{tabular}




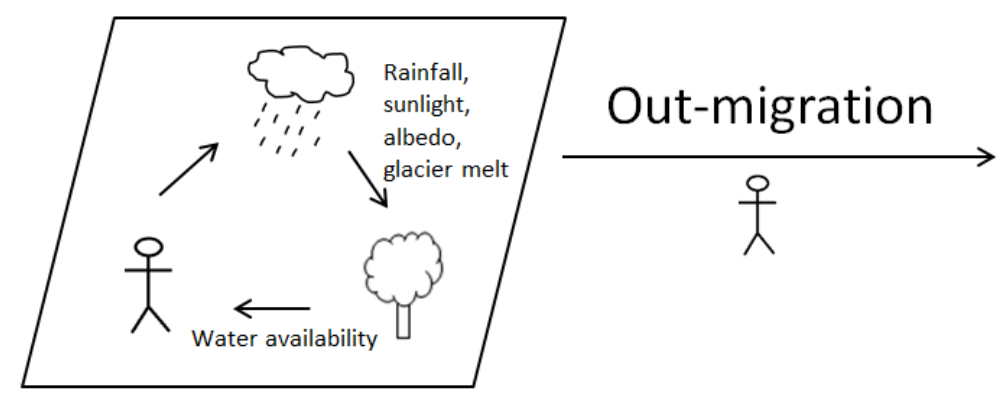

?

Fig. A1.6 Diagram drafted for the ABM described by Magallanes et al. (2014)

Table A1.6 Standardized protocol for the ABM described by Magallanes et al. (2014)

\begin{tabular}{|c|c|c|c|c|c|c|}
\hline \multicolumn{7}{|l|}{ General } \\
\hline \multicolumn{7}{|c|}{$\begin{array}{l}\text { Reference(s): } \\
\text { Magallanes, J. M., A. Burger, and C. Cioffi-Revilla. 2014. Understanding migration induced by } \\
\text { climate change in the Central Andes of Peru via agent-based computational modeling. In J. Sichman, } \\
\text { E. MacKerrow, F. Squazzoni, and T. Terano, editors. Proceedings of the 5th World Congress on } \\
\text { Social Simulation. Sao Paolo, Brazil. }\end{array}$} \\
\hline \multicolumn{4}{|c|}{$\begin{array}{l}\text { Purpose of the study } \\
\text { 1. System understanding } \\
\text { 2. Prediction (quantitative) } \\
\text { 3. Management or decision } \\
\text { support } \\
\text { 4. Communication (participatory } \\
\text { approaches) }\end{array}$} & \multicolumn{3}{|c|}{$\begin{array}{l}\text { Case study } \\
{[\mathrm{Y}] \mathrm{es} /[\mathrm{N}] \mathrm{o} /[\mathrm{C}] \text { ontext-specific }} \\
\text { conceptual model } \\
\text { Huancayo region, Peru }\end{array}$} \\
\hline \multicolumn{3}{|c|}{$\begin{array}{l}\text { Spatial scale } \\
\text { A region covering appox. } 400 \mathrm{~km}^{2} \text { subdivided } \\
\text { into } 5 \text { regions }\end{array}$} & \multicolumn{4}{|c|}{\begin{tabular}{|l|} 
Temporal scale \\
Monthly time steps, total extent not stated
\end{tabular}} \\
\hline \multicolumn{7}{|l|}{ Migration process } \\
\hline \multicolumn{3}{|l|}{$\begin{array}{ll}\text { Migration flow } \\
\text { 1. } & \text { Out-migration } \\
\text { 2. } & \text { Direct return } \\
\text { 3. } & \text { Indirect return } \\
\end{array}$} & \multicolumn{2}{|c|}{$\begin{array}{l}\text { Agents know situation } \\
\text { at destination } \\
\text { 1. Yes } \\
\text { 2. No } \\
\end{array}$} & \multicolumn{2}{|c|}{\begin{tabular}{|ll} 
Duration \\
1. & Seasonal \\
2. & Permanent \\
3. & Both \\
\end{tabular}} \\
\hline \multicolumn{7}{|l|}{ Migration decision } \\
\hline $\begin{array}{l}\text { Number of } \\
\text { environmental } \\
\text { influence } \\
\text { factors: } 5\end{array}$ & \multicolumn{3}{|c|}{$\begin{array}{l}\text { Which factor: } \\
\text { Water availability, seasonal rainfall, glacier melt } \\
\text { affected by sunlight luminosity and glacier } \\
\text { albedo }\end{array}$} & \multicolumn{2}{|c|}{$\begin{array}{l}\text { Type } \\
\text { 1. Abiotic } \\
\text { 2. } \text { Biotic }\end{array}$} & $\begin{array}{l}\text { Direct/indirect } \\
\text { 1. } \quad \text { Direct } \\
\text { 2. } \\
\text { Indirect }\end{array}$ \\
\hline
\end{tabular}




\begin{tabular}{l|l|l|l}
\hline $\begin{array}{l}\text { Other influence } \\
\text { factors }\end{array}$ & $\begin{array}{l}\text { Which factor: } \\
\text { Education, economic level, belonging to a } \\
\text { family, success in trading, number of neighbors }\end{array}$ & $\begin{array}{l}\text { Social } \\
\text { network } \\
1 . \quad \text { Yes } \\
2 . \quad \text { No }\end{array}$ & How: \\
$\begin{array}{ll}\text { 1. Economic } \\
\text { 2. Social }\end{array}$ & & & \\
3. Both & & & \\
\hline
\end{tabular}

\section{Methodology}

1. Probability function

2. Decision theory

3. Heuristic

4. Optimization

\begin{tabular}{l|l}
\hline \multicolumn{2}{l}{ Social-ecological feedbacks } \\
\hline \multicolumn{2}{l}{ Type of coupling } \\
1. One-way linkage \\
2. Partly integrated linkages \\
3. Fully integrated two-way linkages \\
\hline \multicolumn{2}{l}{ Other decision processes (besides migration) } \\
\hline Object of decision making & Other \\
1. Cropping & \\
2. Livestock & \\
3. Hunting & \\
4. Other & \\
5. None & \\
\hline
\end{tabular}


Mena et al. 2011

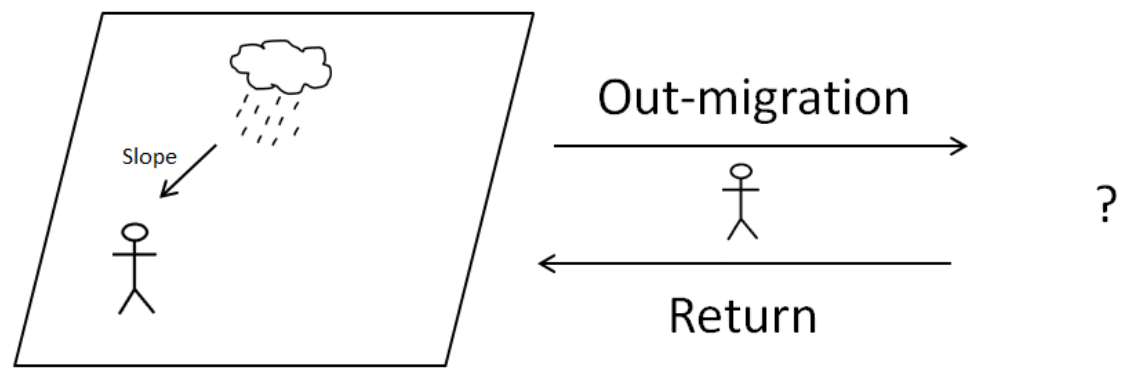

Fig. A1.7 Diagram drafted for the ABM described by Mena et al. (2011)

Table A1.7 Standardized protocol for the ABM described by Mena et al. (2011)

General

Reference(s):

Mena, C. F., S. J. Walsh, B. G. Frizzelle, Y. Xiaozheng, and G. P. Malanson. 2011. Land use change on household farms in the Ecuadorian Amazon: design and implementation of an agent-based model.

Applied Geography 31(1):210-222.

\section{Purpose of the study}

1. System understanding

2. Prediction (quantitative)

3. Management or decision support

4. Communication (participatory multiple criteria possible approaches)
5. Theory development

6. Hypothesis testing

7. Not clearly stated

\section{Case study}

$[\mathrm{Y}] \mathrm{es} /[\mathrm{N}] \mathrm{o} /[\mathrm{C}]$ ontext-specific conceptual model

Northern Ecuadorian Amazon

\section{Spatial scale}

approx. 20,000 $\mathrm{km}^{2}$, size of all farms is 50ha

Temporal scale

25 years in annual time steps

\section{Migration process \\ Migration flow}

1. Out-migration

2. Direct return

4. Out of system

3. Indirect return

\begin{tabular}{|c|c|}
\hline $\begin{array}{l}\text { Agents know situation } \\
\text { at destination } \\
\text { 1. Yes } \\
\text { 2. No }\end{array}$ & $\begin{array}{ll}\text { Duration } \\
\text { 1. } \\
\text { 2. } & \text { Peasonal } \\
\text { 3. } & \text { Bothanent }\end{array}$ \\
\hline \begin{tabular}{ll}
\multicolumn{2}{l}{ Type } \\
1. & Abiotic \\
2. & Biotic
\end{tabular} & $\begin{array}{ll}\text { Direct/indirect } \\
\text { 1. } & \text { Direct } \\
\text { 2. } & \text { Indirect }\end{array}$ \\
\hline
\end{tabular}

\section{Migration decision}

\begin{tabular}{l|l|l|l}
\hline $\begin{array}{l}\text { Number of } \\
\text { environmental } \\
\text { influence factors: } 1\end{array}$ & Which factor: & Type & Direct/indirect \\
& & $\begin{array}{l}\text { Slope Abiotic } \\
\text { 2. Biotic }\end{array}$ & 2. Direct \\
& &
\end{tabular}




\begin{tabular}{|c|c|c|c|}
\hline $\begin{array}{l}\text { Other influence } \\
\text { factors } \\
\text { 1. Economic } \\
\text { 2. Social } \\
\text { 3. Both }\end{array}$ & $\begin{array}{l}\text { Which factor: } \\
\text { Assets (influenced by } \\
\text { market prices \& } \\
\text { maintenance costs), } \\
\text { age; gender; number } \\
\text { of persons in } \\
\text { household; } \\
\text { engagement in farm } \\
\text { work; household's } \\
\text { head education; } \\
\text { number of previous } \\
\text { out-migrants in the } \\
\text { household; population } \\
\text { density at the farm; } \\
\text { walking distance to } \\
\text { the nearest road; } \\
\text { distance to nearest } \\
\text { market; land use } \\
\text { change in crops, } \\
\text { pasture and forest } \\
\text { from } 1990 \text { to } 1999\end{array}$ & $\begin{array}{l}\text { Social network } \\
\text { 1. Yes } \\
\text { 2. No }\end{array}$ & How: \\
\hline
\end{tabular}

Methodology

1. Probability function

2. Decision theory

3. Heuristic

4. Optimization

Social-ecological feedbacks

Type of coupling

1. One-way linkage

2. Partly integrated linkages

3. Fully integrated two-way linkages




Naivinit et al. 2010
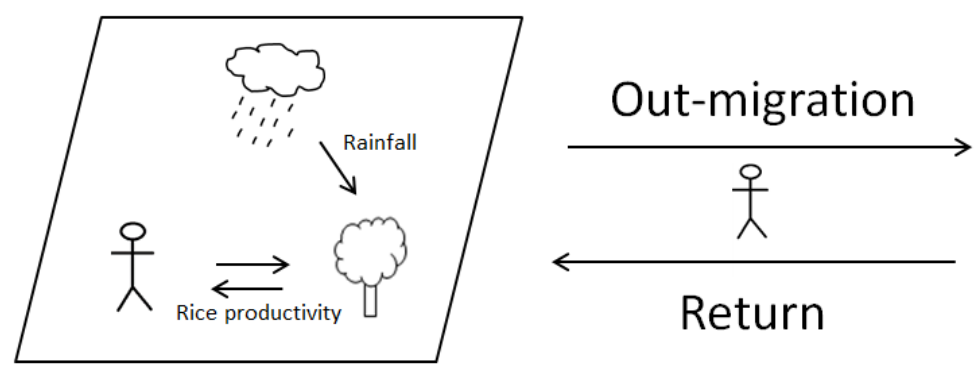

\section{?}

Fig. A1.8 Diagram drafted for the ABM described by Naivinit et al. (2010)

Table A1.8 Standardized protocol for the ABM described by Naivinit et al. (2010)

\begin{tabular}{|c|c|c|c|c|c|}
\hline \multicolumn{6}{|l|}{ General } \\
\hline \multicolumn{6}{|c|}{$\begin{array}{l}\text { Reference(s): } \\
\text { Naivinit, W., C. Le Page, G. Trébuil, and N. Gajaseni. 2010. Participatory agent-based modeling and } \\
\text { simulation of rice production and labor migrations in northeast Thailand. Environmental Modelling \& } \\
\text { Software 25(11):1345-1358. }\end{array}$} \\
\hline \multicolumn{4}{|c|}{$\begin{array}{l}\text { Purpose of the study } \\
\text { 1. } \quad \text { System understanding } \\
\text { 2. Prediction (quantitative) } \\
\text { 3. Management or decision } \\
\text { support } \\
\text { 4. } \quad \text { Communication (participatory } \\
\text { approaches) }\end{array}$} & \multicolumn{2}{|c|}{$\begin{array}{l}\text { Case study } \\
{[\mathrm{Y}] \mathrm{es} /[\mathrm{N}] \mathrm{o} /[\mathrm{C}] \text { ontext-specific }} \\
\text { conceptual model } \\
\text { Ban Mak Mai village, Northeast } \\
\text { Thailand }\end{array}$} \\
\hline \multicolumn{3}{|c|}{$\begin{array}{l}\text { Spatial scale } \\
\text { Local (one village); } 4 \text { households ( } 2 * 3.6 \text { ha and } \\
\text { 2*7ha); resolution } 0.04 \text { ha; abstract landscape } \\
\text { setting }\end{array}$} & \multicolumn{3}{|c|}{$\begin{array}{l}\text { Temporal scale } \\
10 \text { years; daily time steps; migration decision only } \\
\text { once a year }\end{array}$} \\
\hline \multicolumn{6}{|l|}{ Migration process } \\
\hline \multicolumn{3}{|l|}{$\begin{array}{ll}\text { Migration flow } \\
\text { 1. } & \text { Out-migration } \\
\text { 2. } & \text { Direct return } \\
\text { 3. } & \text { Indirect return }\end{array}$} & \multicolumn{2}{|c|}{$\begin{array}{l}\text { Agents know situation } \\
\text { at destination } \\
\text { 1. Yes } \\
\text { 2. No }\end{array}$} & $\begin{array}{ll}\text { Duration } \\
\text { 1. Seasonal } \\
\text { 2. Permanent } \\
\text { 3. } \text { Both }\end{array}$ \\
\hline \multicolumn{6}{|l|}{ Migration decision } \\
\hline $\begin{array}{l}\text { Number of } \\
\text { environmental } \\
\text { influence factors: } 2\end{array}$ & \multicolumn{2}{|c|}{$\begin{array}{l}\text { Which factor: } \\
\text { Rainfall, Rice } \\
\text { productivity }\end{array}$} & \multicolumn{2}{|c|}{$\begin{array}{ll}\text { Type } \\
\text { 1. } & \text { Abiotic (rain) } \\
\text { 2. } & \text { Biotic (rice } \\
& \text { productivity) }\end{array}$} & \begin{tabular}{ll}
\multicolumn{2}{l}{ Direct/indirect } \\
1. & Direct \\
2. & Indirect
\end{tabular} \\
\hline
\end{tabular}




\begin{tabular}{|c|c|c|c|}
\hline $\begin{array}{l}\text { Other influence } \\
\text { factors } \\
\text { 1. Economic } \\
\text { 2. Social } \\
\text { 3. Both }\end{array}$ & $\begin{array}{l}\text { Which factor: } \\
\text { Age, gender, marital } \\
\text { status, migration } \\
\text { experience, income at } \\
\text { household level, } \\
\text { dependent at home }\end{array}$ & $\begin{array}{l}\text { Social network } \\
\text { 1. Yes } \\
\text { 2. No }\end{array}$ & $\begin{array}{l}\text { How: } \\
\text { Individuals belong to } \\
\text { households; dependents } \\
\text { in household influence } \\
\text { migration decisions }\end{array}$ \\
\hline
\end{tabular}

\section{Methodology}

1. Probability function

2. Decision theory

3. Heuristic

4. Optimization

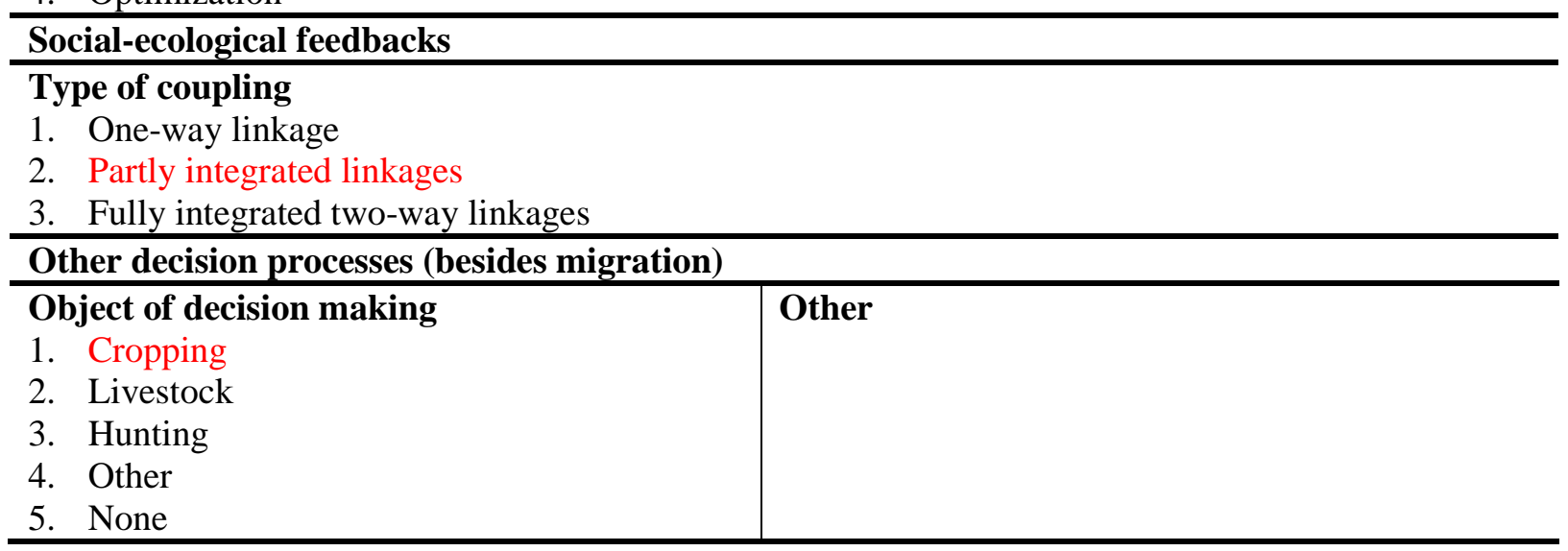




\section{Naqvi \& Rehm 2014}

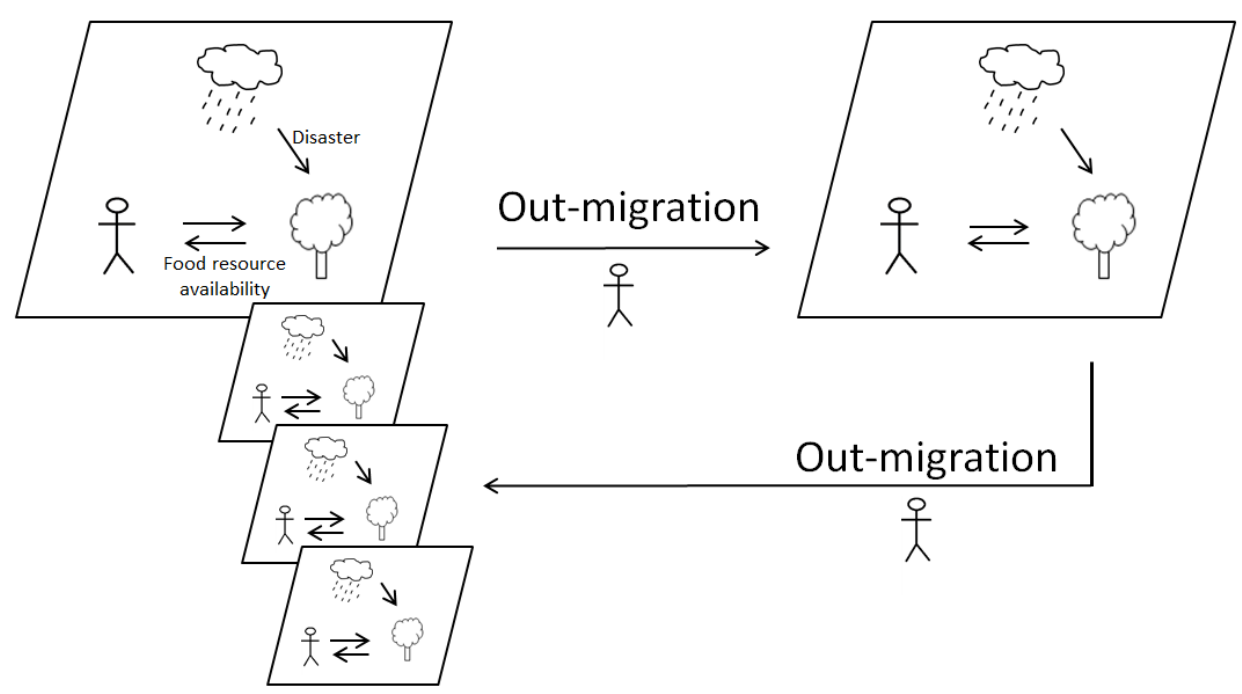

Fig. A1.9 Diagram drafted for the ABM described by Naqvi \& Rehm (2014); agents do not make explicit return decisions, but migrate from region to region and can thereby visit a region again at some point in the future

Table A1.9 Standardized protocol for the ABM described by Naqvi \& Rehm (2014)

\section{General}

Reference(s):

Naqvi, A. A., and M. Rehm. 2014. A multi-agent model of a low income economy: simulating the distributional effects of natural disasters. Journal of Economic Interaction and Coordination 9(2):275309.

\section{Purpose of the study}

1. System understanding

2. Prediction (quantitative)

3. Management or decision support

4. Communication (participatory approaches)

\section{Spatial scale}

9 villages and 3 cities linked through a road network
5. Theory development

6. Hypothesis testing

7. Not clearly stated

Case study

$[\mathrm{Y}] \mathrm{es} /[\mathrm{N}] \mathrm{o} /[\mathrm{C}]$ ontext-specific conceptual model

Punjab region in rural Pakistan

multiple criteria possible 
Migration process

Migration flow

1. Out-migration

4. Out of system

Agents know situation

Duration

2. Direct return

5. Into system

at destination

1. Seasonal

3. Indirect return

1. Yes

2. Permanent

2. No

3. Both

\begin{tabular}{|c|c|c|c|}
\hline \multicolumn{4}{|l|}{ Migration decision } \\
\hline $\begin{array}{l}\text { Number of } \\
\text { environmental } \\
\text { influence factors: } 2\end{array}$ & $\begin{array}{l}\text { Which factor: } \\
\text { abstract disaster } \\
\text { interpreted as } \\
\text { flooding, but not } \\
\text { modeled explicitly, } \\
\text { food resource } \\
\text { availability }\end{array}$ & \begin{tabular}{ll}
\multicolumn{2}{l}{ Type } \\
1. & Abiotic (disaster) \\
2. & Biotic (food \\
& production)
\end{tabular} & $\begin{array}{ll}\text { Direct/indirect } \\
\text { 1. } & \text { Direct } \\
\text { 2. } & \text { Indirect }\end{array}$ \\
\hline 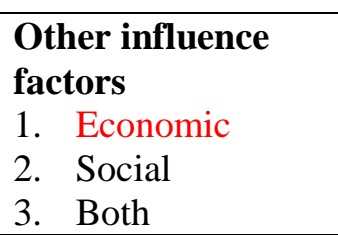 & $\begin{array}{l}\text { Which factor: } \\
\text { Distance, income }\end{array}$ & $\begin{array}{l}\text { Social network } \\
\text { 1. Yes } \\
\text { 2. No }\end{array}$ & How: \\
\hline \begin{tabular}{ll}
\multicolumn{2}{l}{ Methodology } \\
1. & Probability funct \\
2. Decision theory \\
3. Heuristic \\
4. \\
Optimization
\end{tabular} & & & \\
\hline \multicolumn{4}{|c|}{ Social-ecological feedbacks } \\
\hline $\begin{array}{l}\text { Type of coupling } \\
\text { 1. One-way linkage } \\
\text { 2. Partly integrated } \\
\text { 3. } \text { Fully integrated t } \\
\end{array}$ & $\begin{array}{l}\text { ages } \\
\text { way linkages }\end{array}$ & & \\
\hline \multicolumn{4}{|c|}{ Other decision processes (besides migration) } \\
\hline $\begin{array}{ll}\text { Object of decision } \mathbf{~} \\
\text { 1. } & \text { Cropping } \\
\text { 2. } & \text { Livestock } \\
\text { 3. } & \text { Hunting } \\
\text { 4. } & \text { Other } \\
\text { 5. } & \text { None }\end{array}$ & & \multicolumn{2}{|c|}{$\begin{array}{l}\text { Other } \\
\text { Related to economic interactions (hiring workers, } \\
\text { selling and buying goods) }\end{array}$} \\
\hline
\end{tabular}




\section{Rogers et al. 2011}

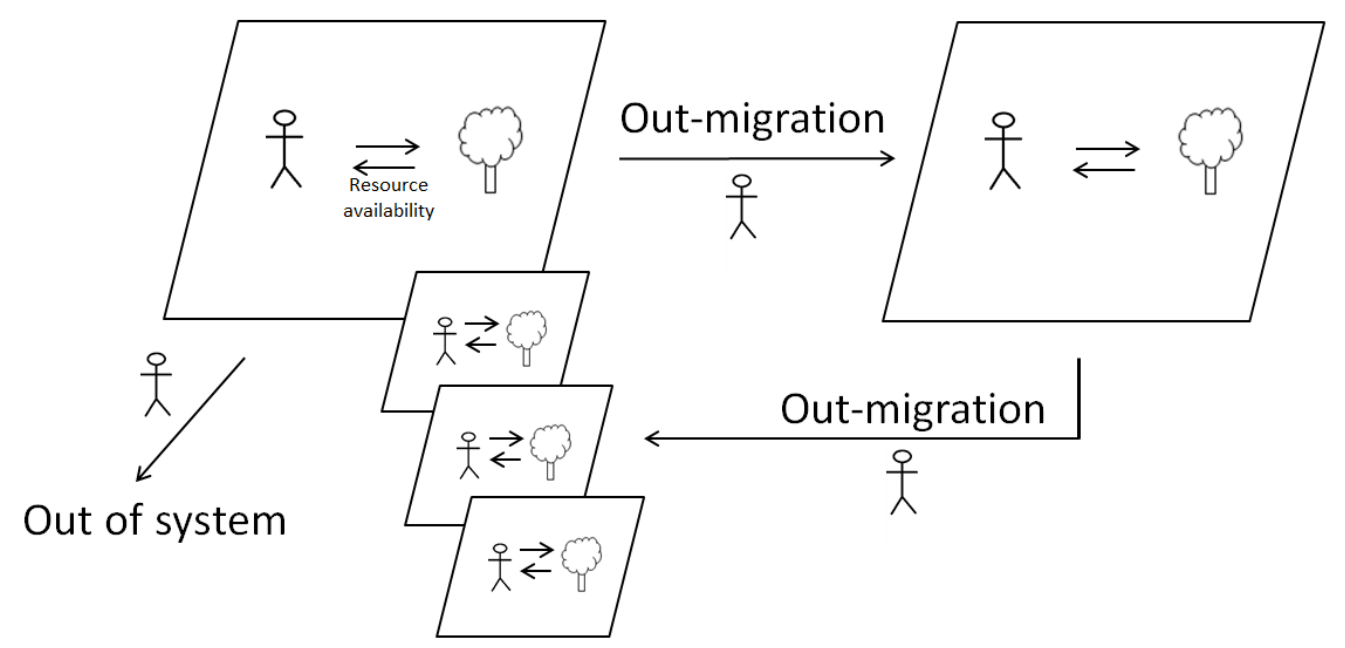

Fig. A1.10 Diagram drafted for the ABM described by Rogers et al. (2011); agents do not make explicit return decisions, but migrate from region to region and can thereby visit a region again at some point in the future; migration out of the system is possible from all subsystems, but for simplicity reasons it is only visualized for the origin system; the situation in the destination system does not influence the migration decision, but as agents interact with the environment in all visited systems these factors are visualized

Table A1.10 Standardized protocol for the ABM described by Rogers et al. (2011)

\section{General}

Reference(s):

Rogers, D. S., O. Deshpande, and M. W. Feldman. 2011. The spread of inequality. PLoS ONE 6(9):e24683.

\section{Purpose of the study}

1. System understanding

2. Prediction (quantitative)

3. Management or decision support

4. Communication (participatory multiple criteria possible approaches)
5. Theory development

6. Hypothesis testing

7. Not clearly stated

\section{Case study}

$[\mathrm{Y}] \mathrm{es} /[\mathrm{N}] \mathrm{o} /[\mathrm{C}]$ ontext-specific conceptual model 


\begin{tabular}{|c|c|c|c|}
\hline \multicolumn{2}{|c|}{$\begin{array}{l}\text { Spatial scale } \\
100 \text { sites with same size }\end{array}$} & \multicolumn{2}{|c|}{$\begin{array}{l}\text { Temporal scale } \\
\text { Yearly time steps for } 2000 \text { years }\end{array}$} \\
\hline \multicolumn{4}{|l|}{ Migration process } \\
\hline $\begin{array}{ll}\text { Migration flow } \\
\text { 1. } & \text { Out-migration } \\
\text { 2. } & \text { Direct return } \\
\text { 3. } & \text { Indirect return }\end{array}$ & $\begin{array}{l}\text { 4. Out of system } \\
\text { 5. Into system }\end{array}$ & $\begin{array}{l}\text { Agents know situation } \\
\text { at destination } \\
\text { 1. Yes } \\
\text { 2. No }\end{array}$ & $\begin{array}{ll}\text { Duration } \\
\text { 1. } & \text { Seasonal } \\
\text { 2. } & \text { Permanent } \\
\text { 3. } & \text { Both }\end{array}$ \\
\hline \multicolumn{4}{|l|}{ Migration decision } \\
\hline $\begin{array}{l}\text { Number of } \\
\text { environmental } \\
\text { influence factors: } 1\end{array}$ & $\begin{array}{l}\text { Which factor: } \\
\text { Resource availability }\end{array}$ & \begin{tabular}{ll}
\multicolumn{2}{l}{ Type } \\
1. & Abiotic \\
2. & Biotic \\
\end{tabular} & $\begin{array}{ll}\text { Direct/indirect } \\
\text { 1. } & \text { Direct } \\
\text { 2. } & \text { Indirect }\end{array}$ \\
\hline 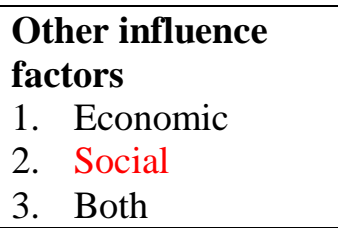 & $\begin{array}{l}\text { Which factor: } \\
\text { Population decline }\end{array}$ & $\begin{array}{l}\text { Social network } \\
\text { 1. Yes } \\
\text { 2. No }\end{array}$ & How: \\
\hline
\end{tabular}

\section{Methodology}

1. Probability function

2. Decision theory

3. Heuristic

4. Optimization

Social-ecological feedbacks

Type of coupling

1. One-way linkage

2. Partly integrated linkages

3. Fully integrated two-way linkages

\begin{tabular}{l|l}
\hline \multicolumn{2}{l}{ Other decision processes (besides migration) } \\
\hline Object of decision making & Other \\
1. Cropping & \\
2. Livestock & \\
3. Hunting & \\
4. Other & \\
5. None & \\
\hline
\end{tabular}




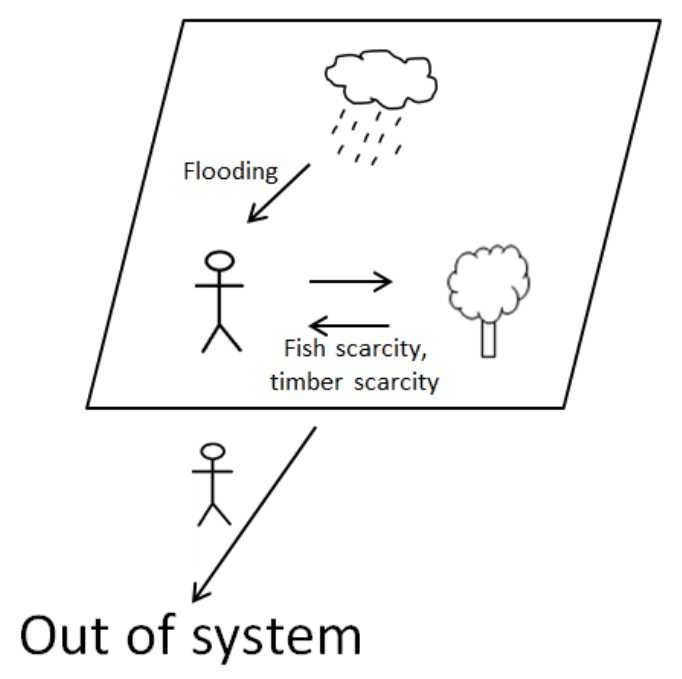

Fig. A1.11 Diagram drafted for the ABM described by Smajgl \& Bohensky (2013) and Smajgl et al. (2009)

Table A1.11 Standardized protocol for the ABM described by Smajgl \& Bohensky (2013) and Smajgl et al. (2009)

\section{General}

Reference(s):

Smajgl, A., and E. Bohensky. 2013. Behaviour and space in agent-based modelling: poverty patterns in East Kalimantan, Indonesia. Environmental Modelling \& Software 45:8-14.

Smajgl, A., G. Carlin, A. House, J. Butler, E. Bohensky, A. S. Kurnia, C. Sugiyanto, and M. Hodgen. 2009. Design document for agent-based model SimPaSI Jawa Tengah. Simulating pathways to sustainability in Indonesia. CSIRO, Townsville, Australia.

\section{Purpose of the study}

1. System understanding

2. Prediction (quantitative)

3. Management or decision support

4. Communication (participatory approaches)

\section{Spatial scale}

study area consists of six southern districts of
5. Theory development

6. Hypothesis testing

7. Not clearly stated

multiple criteria possible

\section{Case study}

$[\mathrm{Y}] \mathrm{es} /[\mathrm{N}] \mathrm{o} /[\mathrm{C}]$ ontext-specific conceptual model

East Kalimantan, Indonesia

\section{Temporal scale}

Combination of daily (environment) and weekly 


\begin{tabular}{|c|c|c|c|}
\hline \multicolumn{2}{|c|}{ East Kalimantan (approx. 220.4} & \multicolumn{2}{|c|}{ (households) time steps, 2006 to 2013} \\
\hline \multicolumn{4}{|l|}{ Migration process } \\
\hline $\begin{array}{ll}\text { Migration flow } \\
\text { 1. } & \text { Out-migration } \\
\text { 2. } & \text { Direct return } \\
\text { 3. } & \text { Indirect return }\end{array}$ & $\begin{array}{l}\text { 4. Out of system } \\
\text { 5. Into system }\end{array}$ & $\begin{array}{l}\text { Agents know situation } \\
\text { at destination } \\
\text { 1. Yes } \\
\text { 2. No }\end{array}$ & $\begin{array}{ll}\text { Duration } \\
\text { 1. } \\
\text { 2. } \text { Peasonal } \\
\text { 3. } \text { Bothanent }\end{array}$ \\
\hline \multicolumn{4}{|l|}{ Migration decision } \\
\hline $\begin{array}{l}\text { Number of } \\
\text { environmental } \\
\text { influence factors: } 3\end{array}$ & $\begin{array}{l}\text { Which factor: } \\
\text { Flooding, timber, fish } \\
\text { scarcity }\end{array}$ & $\begin{array}{l}\text { Type } \\
\text { 1. Abiotic (flooding) } \\
\text { 2. Biotic (fish scarcity } \\
\text { and timber) }\end{array}$ & $\begin{array}{l}\text { Direct/indirect } \\
\text { 1. } \\
\text { 2. } \\
\begin{array}{l}\text { Indirect } \\
\text { affects forest } \\
\text { economy) }\end{array}\end{array}$ \\
\hline 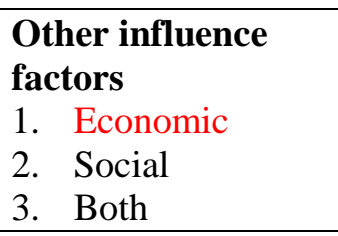 & $\begin{array}{l}\text { Which factor: } \\
\text { Fuel price, } \\
\text { groundwater price, } \\
\text { electricity price, } \\
\text { kerosene price } \\
\end{array}$ & $\begin{array}{l}\text { Social network } \\
\text { 1. Yes } \\
\text { 2. No }\end{array}$ & How: \\
\hline \multicolumn{4}{|c|}{$\begin{array}{l}\text { 1. Probability function } \\
\text { 2. Decision theory } \\
\text { 3. Heuristic } \\
\text { 4. Optimization }\end{array}$} \\
\hline \multicolumn{4}{|c|}{ Social-ecological feedbacks } \\
\hline 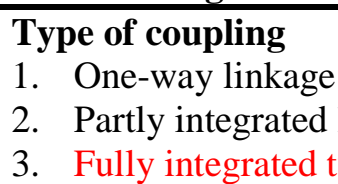 & $\begin{array}{l}\text { ages } \\
\text { way linkages }\end{array}$ & & \\
\hline \multicolumn{4}{|c|}{ Other decision processes (besides migration) } \\
\hline $\begin{array}{ll}\text { Object of decision } \mathbf{m} \\
\text { 1. } & \text { Cropping } \\
\text { 2. } & \text { Livestock } \\
\text { 3. } & \text { Hunting } \\
\text { 4. } & \text { Other } \\
\text { 5. } & \text { None }\end{array}$ & & \multicolumn{2}{|c|}{$\begin{array}{l}\text { Other } \\
\text { use of different natural resources (fish, timber) }\end{array}$} \\
\hline
\end{tabular}




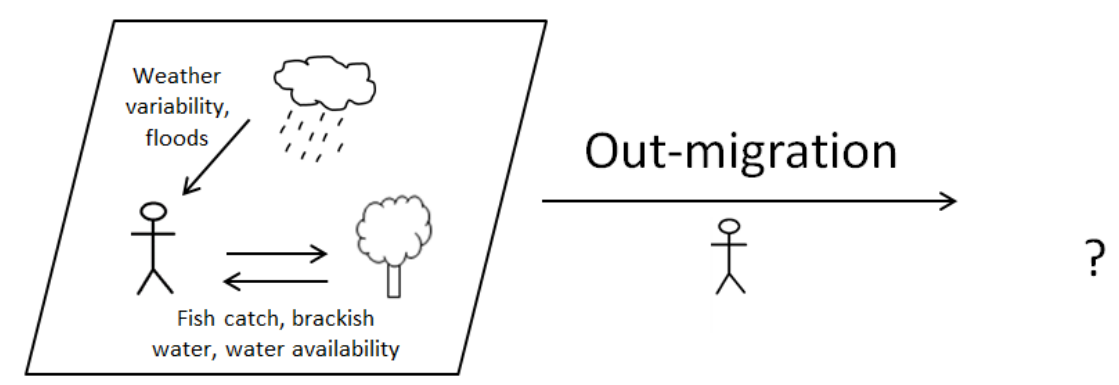

Fig. A1.12 Diagram drafted for the ABM described by Smajgl et al. (2013; 2015a; 2015b)

Table A1.12 Standardized protocol for the ABM described by Smajgl et al. (2013; 2015a;

$$
\text { 2015b) }
$$

\begin{tabular}{|c|c|c|}
\hline \multicolumn{3}{|l|}{ General } \\
\hline \multicolumn{3}{|c|}{$\begin{array}{l}\text { Reference(s): } \\
\text { Smajgl, A., S. Egan, M. Kirby, M. Mainuddin, J. Ward, and F. Kroon. 2013. The Mekong Region } \\
\text { simulation (Mersim) model - design document. CSIRO Climate Adaptation Flagship, Townsville, } \\
\text { Australia. } \\
\text { Smajgl, A., J. Xu, S. Egan, Z.-F. Yi, J. Ward, and Y. Su. 2015a. Assessing the effectiveness of } \\
\text { payments for ecosystem services for diversifying rubber in Yunnan, China. Environmental Modelling } \\
\text { \& Software 69:187-195. } \\
\text { Smajgl, A., J. R. Ward, T. Foran, J. Dore, and S. Larson. 2015b. Visions, beliefs, and transformation: } \\
\text { exploring cross-sector and transboundary dynamics in the wider Mekong region. Ecology and Society } \\
\text { 20(2):15. }\end{array}$} \\
\hline \multicolumn{2}{|l|}{$\begin{array}{l}\text { Purpose of the study } \\
\text { 1. System understanding } \\
\text { 2. Prediction (quantitative) } \\
\text { 3. Management or decision } \\
\text { support } \\
\text { 4. } \text { Communication (participatory } \\
\text { approaches) }\end{array}$} & $\begin{array}{l}\text { Case study } \\
{[\mathrm{Y}] \mathrm{es} /[\mathrm{N}] \mathrm{o} /[\mathrm{C}] \text { ontext-specific }} \\
\text { conceptual model }\end{array}$ \\
\hline $\begin{array}{l}\text { Spatial scale } \\
\text { Extent: Greater Mekong Subregion } \\
\text { Resolution: Irregular polygons derived from } \\
\text { overlapping various GIS layers (incl. elevation } \\
\text { and land cover). }\end{array}$ & \multicolumn{2}{|c|}{$\begin{array}{l}\text { Temporal scale } \\
\text { Daily time steps; scenarios up to } 2029\end{array}$} \\
\hline
\end{tabular}


Migration process

Migration flow

1. Out-migration

4. Out of system

Agents know situation

Duration

2. Direct return

5. Into system

at destination

1. Seasonal

3. Indirect return

1. Yes

2. Permanent

2. No

3. Both

\begin{tabular}{|c|c|c|c|}
\hline \multicolumn{4}{|l|}{ Migration decision } \\
\hline $\begin{array}{l}\text { Number of } \\
\text { environmental } \\
\text { influence factors: } 5\end{array}$ & $\begin{array}{l}\text { Which factor: } \\
\text { Loss of fish catch, } \\
\text { increasing weather } \\
\text { variability, water } \\
\text { availability, more } \\
\text { brackish water, small } \\
\text { floods }\end{array}$ & $\begin{array}{l}\text { Type } \\
\text { 1. Abiotic (weather } \\
\text { variability, water } \\
\text { availability, floods) } \\
\text { 2. } \begin{array}{l}\text { Biotic (fish catch, } \\
\text { brackish water) }\end{array}\end{array}$ & $\begin{array}{l}\text { Direct/indirect } \\
\text { 1. Direct } \\
\text { 2. Indirect }\end{array}$ \\
\hline 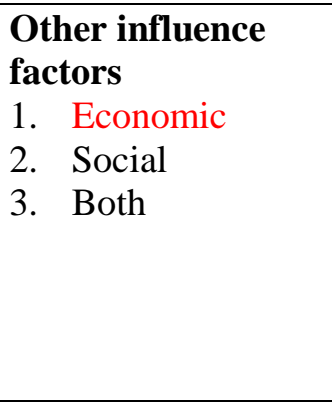 & $\begin{array}{l}\text { Which factor: } \\
\text { Income changes, } \\
\text { industry employment } \\
\text { conditions, market } \\
\text { access, irrigation } \\
\text { scheme, competition } \\
\text { among water users, } \\
\text { rubber tree } \\
\text { replacement }\end{array}$ & $\begin{array}{l}\text { Social network } \\
\text { 1. Yes } \\
\text { 2. No }\end{array}$ & How: \\
\hline
\end{tabular}

\section{Methodology}

1. Probability function

2. Decision theory

3. Heuristic

4. Optimization

Social-ecological feedbacks

Type of coupling

1. One-way linkage

2. Partly integrated linkages

3. Fully integrated two-way linkages

\begin{tabular}{l|l}
\hline \multicolumn{2}{l}{ Other decision processes (besides migration) } \\
\hline Object of decision making & Other \\
1. Cropping & Use of different natural resources (fish, timber), get \\
2. Livestock & income from livelihood activities, modify \\
3. Hunting & livelihood as form of adaptation \\
4. Other & \\
5. None & \\
\hline
\end{tabular}




\section{Smith 2014}

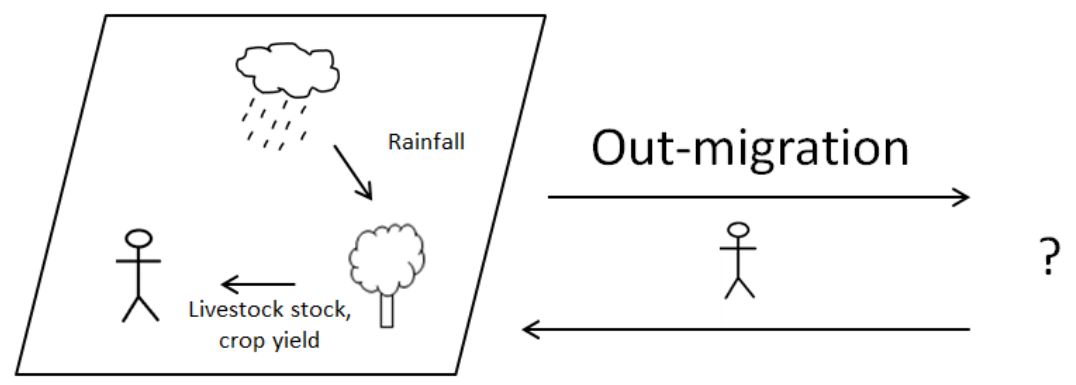

Fig. A1.13 Diagram drafted for the ABM described by Smith (2014); migrants send

remittances back to their household and are therefore not deleted from the system (i.e. this is

$$
\text { not „migration out of the system“) }
$$

Table A1.13 Standardized protocol for the ABM described by Smith (2014)

\begin{tabular}{|c|c|c|c|c|}
\hline \multicolumn{5}{|l|}{ General } \\
\hline \multicolumn{5}{|l|}{$\begin{array}{l}\text { Reference(s): } \\
\text { Smith, C. D. 2014. Modelling }\end{array}$} \\
\hline \multicolumn{3}{|l|}{$\begin{array}{l}\text { Purpose of the study } \\
\text { 1. System understanding } \\
\text { 2. Prediction (quantitative) } \\
\text { 3. Management or decision } \\
\text { support } \\
\text { 4. Communication (participatory } \\
\text { approaches) }\end{array}$} & \multicolumn{2}{|c|}{$\begin{array}{l}\text { Case study } \\
{[\mathrm{Y}] \text { es/[N]o/[C]ontext-specific }} \\
\text { conceptual model } \\
\text { Kilimanjaro Region, Tanzania }\end{array}$} \\
\hline \multicolumn{2}{|c|}{$\begin{array}{l}\text { Spatial scale } \\
3 \text { villages as } 3 \text { entities, not spatially explicit }\end{array}$} & \multicolumn{3}{|c|}{$\begin{array}{l}\text { Temporal scale } \\
\text { Simulation runs from } 2015 \text { to 2050, rainfall } \\
\text { monthly time steps, human decisions also monthly }\end{array}$} \\
\hline \multicolumn{5}{|l|}{ Migration process } \\
\hline \multicolumn{2}{|l|}{$\begin{array}{l}\text { Migration flow } \\
\text { 1. } \text { Out-migration } \\
\text { 2. Direct return } \\
\text { 3. } \\
\text { Indirect return }\end{array}$} & \multicolumn{2}{|c|}{$\begin{array}{l}\text { Agents know situation } \\
\text { at destination } \\
\text { 1. Yes } \\
\text { 2. No }\end{array}$} & $\begin{array}{ll}\text { Duration } \\
\text { 1. } & \text { Seasonal } \\
\text { 2. } & \text { Permanent } \\
\text { 3. } & \text { Both (up to } 72 \\
& \text { months) }\end{array}$ \\
\hline
\end{tabular}




\begin{tabular}{|c|c|c|c|}
\hline \multicolumn{4}{|l|}{ Migration decision } \\
\hline $\begin{array}{l}\text { Number of } \\
\text { environmental } \\
\text { influence factors: } 3\end{array}$ & $\begin{array}{l}\text { Which factor: } \\
\text { Rainfall, crop yield, } \\
\text { livestock stock }\end{array}$ & \begin{tabular}{ll}
\multicolumn{2}{l}{ Type } \\
1. Abiotic (rainfall) \\
2. \\
$\begin{array}{l}\text { Biotic (crop yield, } \\
\text { livestock stock) }\end{array}$
\end{tabular} & $\begin{array}{ll}\text { Direct/indirect } \\
\text { 1. } & \text { Direct } \\
\text { 2. } & \text { Indirect }\end{array}$ \\
\hline $\begin{array}{l}\text { Other influence } \\
\text { factors } \\
\text { 1. Economic } \\
\text { 2. Social } \\
\text { 3. Both }\end{array}$ & $\begin{array}{l}\text { Which factor: } \\
\text { individuals } \\
\text { (individual propensity } \\
\text { of migration): } \\
\text { influence of peers } \\
\text { (proportion of peers } \\
\text { who have already } \\
\text { migrated), age, } \\
\text { gender, home village } \\
\text { households (actual } \\
\text { decision how many } \\
\text { household members } \\
\text { should migrate): } \\
\text { income (dependent on } \\
\text { rainfall), number of } \\
\text { household members } \\
\end{array}$ & $\begin{array}{l}\text { Social network } \\
\text { 1. Yes } \\
\text { 2. No }\end{array}$ & $\begin{array}{l}\text { How: } \\
\text { Households are } \\
\text { randomly linked to } \\
\text { create a network, } \\
\text { different scenarios with } \\
\text { different numbers of } \\
\text { links per household; } \\
\text { migration experience of } \\
\text { others is influencing } \\
\text { own migration decision }\end{array}$ \\
\hline
\end{tabular}

\section{Methodology}

1. Probability function

2. Decision theory

3. Heuristic

4. Optimization

Social-ecological feedbacks

Type of coupling

1. One-way linkage

2. Partly integrated linkages

3. Fully integrated two-way linkages

\begin{tabular}{|c|c|}
\hline Other decision processes (b & \\
\hline $\begin{array}{ll}\text { Object of decision making } \\
\text { 1. } & \text { Cropping } \\
\text { 2. } & \text { Livestock } \\
\text { 3. } & \text { Hunting } \\
\text { 4. } & \text { Other } \\
\text { 5. } & \text { None }\end{array}$ & Other \\
\hline
\end{tabular}




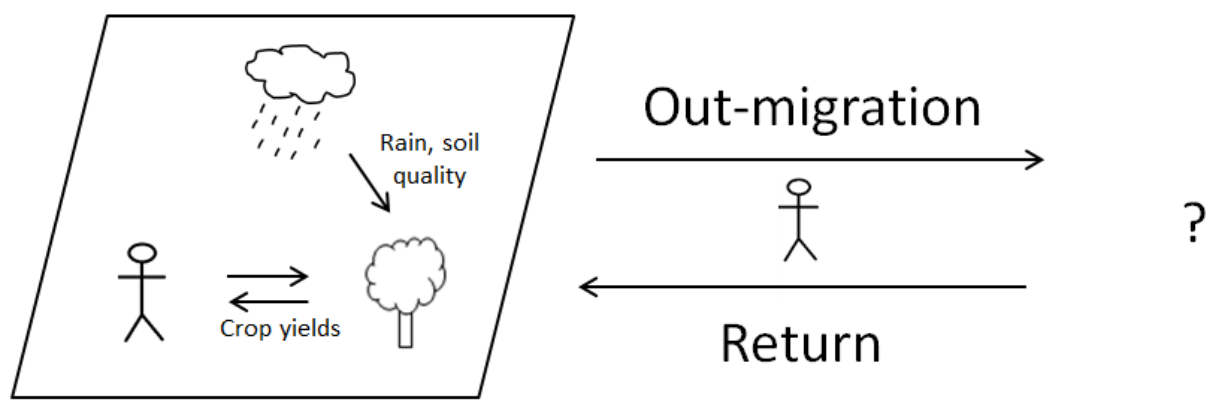

Fig. A1.14 Diagram drafted for the ABM described by Walsh et al. (2013) and Entwisle et al. (2008; 2016)

Table A1.14 Standardized protocol for the ABM described by Walsh et al. (2013) and

Entwisle et al. (2008; 2016)

General

Reference(s):

Walsh, S. J., G. P. Malanson, B. Entwisle, R. R. Rindfuss, P. J. Mucha, B. W. Heumann, P. M. McDaniel, B. G. Frizzelle, A. M. Verdery, N. E. Williams, X. Yao, and D. Ding. 2013. Design of an agent-based model to examine population — environment interactions in Nang Rong District, Thailand. Applied Geography 39:183-198.

Entwisle, B., G. Malanson, R. R. Rindfuss, and S. Walsh. 2008. An agent-based model of household dynamics and land use change. Journal of Land Use Science 3(1):73-93.

Entwisle, B., N. E. Williams, A. M. Verdery, R. R. Rindfuss, S. J. Walsh, G. P. Malanson, P. J. Mucha, B. G. Frizzelle, P. M. McDaniel, X. Yao, B. W. Heumann, P. Prasartkul, Y. Sawangdee, and A. Jampaklay. 2016. Climate shocks and migration: an agent-based modeling approach. Population and Environment 38:47-71.

\section{Purpose of the study}

1. System understanding

2. Prediction (quantitative)

3. Management or decision support

4. Communication (participatory multiple criteria possible approaches)
5. Theory development
6. Hypothesis testing
7. Not clearly stated

\section{Case study}

$[\mathrm{Y}] \mathrm{es} /[\mathrm{N}] \mathrm{o} /[\mathrm{C}]$ ontext-specific

conceptual model

Nang Rong District,

Northeastern Thailand

\begin{tabular}{|c|c|c|}
\hline $\begin{array}{l}\text { Spatial scale } \\
1300 \mathrm{~km}^{\wedge} 2,41 \text { villages, } 5 \mathrm{~m} \text { spatial resolution }\end{array}$ & \multicolumn{2}{|c|}{$\begin{array}{l}\text { Temporal scale } \\
\text { Annual time steps for } 25 \text { years }\end{array}$} \\
\hline \multicolumn{3}{|l|}{ Migration process } \\
\hline $\begin{array}{l}\text { Migration flow } \\
\text { 1. Out-migration }\end{array}$ & $\begin{array}{l}\text { Agents know situation } \\
\text { at destination }\end{array}$ & $\begin{array}{l}\text { Duration } \\
\text { 1. Seasonal }\end{array}$ \\
\hline
\end{tabular}



2. Direct return
5. Into system
1. Yes
2. Permanent
3. Indirect return
2. No
3. Both

\begin{tabular}{|c|c|c|c|}
\hline \multicolumn{4}{|l|}{ Migration decision } \\
\hline $\begin{array}{l}\text { Number of } \\
\text { environmental } \\
\text { influence factors: } 3\end{array}$ & $\begin{array}{l}\text { Which factor: } \\
\text { Rainfall, soil quality } \\
\text { \& type, crop yields }\end{array}$ & $\begin{array}{l}\text { Type } \\
\text { 1. Abiotic (rainfall) } \\
\text { 2. Biotic (soil quality, } \\
\text { crop yields) }\end{array}$ & $\begin{array}{ll}\text { Direct/indirect } \\
\text { 1. } & \text { Direct } \\
\text { 2. } & \text { Indirect }\end{array}$ \\
\hline $\begin{array}{l}\text { Other influence } \\
\text { factors } \\
\text { 1. Economic } \\
\text { 2. Social } \\
\text { 3. } \text { Both }\end{array}$ & $\begin{array}{l}\text { Which factor: } \\
\text { Age, population, } \\
\text { connectivity of } \\
\text { village, migration } \\
\text { prevalence, ties to } \\
\text { migrants and } \\
\text { residents, marital } \\
\text { status, percent village } \\
\text { has pump, percent } \\
\text { village has vehicle, } \\
\text { percent village grows } \\
\text { cassava, household } \\
\text { centrality, gender, } \\
\text { kinship dependency, } \\
\text { distance to nearest } \\
\text { village, percent } \\
\text { village has TV, land } \\
\text { deed }\end{array}$ & $\begin{array}{l}\text { Social network } \\
\text { 1. Yes } \\
\text { 2. No }\end{array}$ & $\begin{array}{l}\text { How: } \\
\text { Households are } \\
\text { connected in a social } \\
\text { network; ties to current } \\
\text { migrants, remittances, } \\
\text { household centrality, } \\
\text { migration prevalence, } \\
\text { village connectivity, } \\
\text { ties to wealthy } \\
\text { households }\end{array}$ \\
\hline
\end{tabular}

Methodology

1. Probability function

2. Decision theory

3. Heuristic

4. Optimization

Social-ecological feedbacks

Type of coupling

1. One-way linkage

2. Partly integrated linkages

3. Fully integrated two-way linkages

\begin{tabular}{|c|c|}
\hline Other decision processes (besides migrati & \\
\hline $\begin{array}{l}\text { Object of decision making } \\
\text { 1. Cropping (land use and fertilizer input) } \\
\text { 2. Livestock } \\
\text { 3. Hunting } \\
\text { 4. Other } \\
\text { 5. None }\end{array}$ & Other \\
\hline
\end{tabular}




\section{Wu et al. 2011}

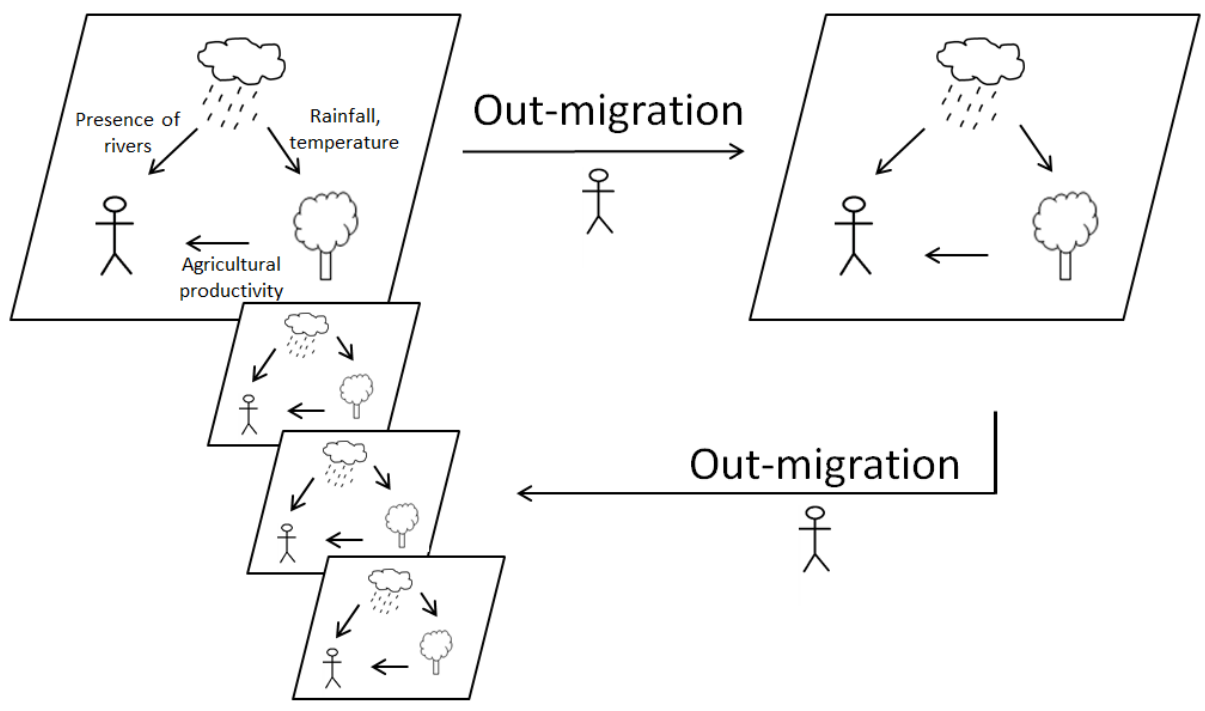

Fig. A1.15 Diagram drafted for the ABM described by Wu et al. (2011); agents do not make explicit return decisions, but migrate from region to region and can thereby visit a region again at some point in the future

Table A1.15 Standardized protocol for the ABM described by Wu et al. (2011)

\begin{tabular}{|c|c|c|}
\hline \multicolumn{3}{|l|}{ General } \\
\hline \multicolumn{3}{|c|}{$\begin{array}{l}\text { Reference(s): } \\
\text { Wu, J., R. Mohamed, and Z. Wang. 2011. Agent-based simulation of the spatial evolution of the } \\
\text { historical population in China. Journal of Historical Geography 37:12-21. }\end{array}$} \\
\hline $\begin{array}{l}\text { Purpose of the study } \\
\text { 1. } \text { System understanding } \\
\text { 2. Prediction (quantitative) } \\
\text { 3. Management or decision } \\
\text { support } \\
\text { 4. Communication (participatory } \\
\text { approaches) }\end{array}$ & $\begin{array}{l}\text { 5. Theory development } \\
\text { 6. Hypothesis testing } \\
\text { 7. Not clearly stated } \\
\text { multiple criteria possible }\end{array}$ & $\begin{array}{l}\text { Case study } \\
{[Y] \text { es/[N]o/[C]ontext-specific }} \\
\text { conceptual model } \\
\text { China }\end{array}$ \\
\hline $\begin{array}{l}\text { Spatial scale } \\
227 * 297 \text { cells a } 468 \mathrm{~km} \wedge 2\end{array}$ & $\begin{array}{l}\text { Temporal } \mathbf{s} \\
2000 \text { years }\end{array}$ & \\
\hline
\end{tabular}


Migration process

Migration flow

1. Out-migration

4. Out of system

Agents know situation

Duration

2. Direct return

5. Into system

at destination

1. Seasonal

3. Indirect return

1. Yes

2. Permanent

2. No

3. Both

\begin{tabular}{|c|c|c|c|}
\hline \multicolumn{4}{|l|}{ Migration decision } \\
\hline $\begin{array}{l}\text { Number of } \\
\text { environmental } \\
\text { influence factors: } 4\end{array}$ & $\begin{array}{l}\text { Which factor: } \\
\text { agricultural } \\
\text { productivity, annual } \\
\text { rainfall, annual } \\
\text { average temperature, } \\
\text { presence of rivers }\end{array}$ & \begin{tabular}{ll}
\multicolumn{2}{l}{ Type } \\
1. Abiotic (rainfall, \\
temperature, river) \\
2. $\begin{array}{l}\text { Biotic (agricultural } \\
\text { productivity) }\end{array}$
\end{tabular} & $\begin{array}{ll}\text { Direct/indirect } \\
\text { 1. } \\
\text { Direct (agricultural } \\
\text { productivity, } \\
\text { rivers) } \\
\text { 2. } \\
\text { Indirect (rainfall, } \\
\text { temperature) }\end{array}$ \\
\hline $\begin{array}{l}\text { Other influence } \\
\text { factors } \\
\text { 1. Economic } \\
\text { 2. Social } \\
\text { 3. Both }\end{array}$ & $\begin{array}{l}\text { Which factor: } \\
\text { Social: Migration } \\
\text { rates, existing } \\
\text { settlements, } \\
\text { population size } \\
\text { Accessibility: } \\
\text { distance between } \\
\text { provinces }\end{array}$ & \begin{tabular}{l}
\multicolumn{2}{l}{ Social network } \\
1. Yes \\
2. No
\end{tabular} & How: \\
\hline $\begin{array}{ll}\text { Methodology } \\
\text { 1. } & \text { Probability funct } \\
\text { 2. } & \text { Decision theory } \\
\text { 3. } & \text { Heuristic } \\
\text { 4. } & \text { Optimization } \\
\end{array}$ & & & \\
\hline \multicolumn{4}{|c|}{ Social-ecological feedbacks } \\
\hline $\begin{array}{l}\text { Type of coupling } \\
\text { 1. } \quad \text { One-way linkage } \\
\text { 2. Partly integrated } \\
\text { 3. } \quad \text { Fully integrated t }\end{array}$ & $\begin{array}{l}\text { ages } \\
\text { way linkages }\end{array}$ & & \\
\hline \multicolumn{4}{|c|}{ Other decision processes (besides migration) } \\
\hline $\begin{array}{ll}\text { Object of decision m } \\
\text { 1. } & \text { Cropping } \\
\text { 2. } & \text { Livestock } \\
\text { 3. } & \text { Hunting } \\
\text { 4. } & \text { Other } \\
\text { 5. } & \text { None }\end{array}$ & & Other & \\
\hline
\end{tabular}




\section{Literature cited}

Berman, M., C. Nicolson, G. Kofinas, J. Tetlichi, and S. Martin. 2004. Adaptation and sustainability in a small Arctic community: results of an agent-based simulation model. Arctic 57(4):401-414. http://dx.doi.org/10.14430/arctic517

Entwisle, B., G. Malanson, R. R. Rindfuss, and S. Walsh. 2008. An agent-based model of household dynamics and land use change. Journal of Land Use Science 3(1):73-93. http://dx.doi.org/10.1080/17474230802048193

Entwisle, B., N. E. Williams, A. M. Verdery, R. R. Rindfuss, S. J. Walsh, G. P. Malanson, P. J. Mucha, B. G. Frizzelle, P. M. McDaniel, X. Yao, B. W. Heumann, P. Prasartkul, Y. Sawangdee, and A. Jampaklay. 2016. Climate shocks and migration: an agent-based modeling approach. Population and Environment 38:47-71. http://dx.doi.org/10.1007/s11111-016-0254y

Hadzibeganovic, T., and C. Xia. 2016. Cooperation and strategy coexistence in a tag-based multiagent system with contingent mobility. Knowledge-Based Systems 112:1-13. http://dx.doi.org/10.1016/j.knosys.2016.08.024

Hassani-Mahmooei, B., and B. W. Parris. 2012. Climate change and internal migration patterns in Bangladesh: an agent-based model. Environment and Development Economics 17:763-780. http://dx.doi.org/10.1017/S1355770X12000290

Janssen, M. A. 2010. Population aggregation in ancient arid environments. Ecology and Society 15(2):19. http://dx.doi.org/10.5751/ES-03376-150219

Kniveton, D. R., C. D. Smith, and R. Black. 2012. Emerging migration flows in a changing climate in dryland Africa. Nature Climate Change 2:444-447. http://dx.doi.org/10.1038/nclimate1447

Kniveton, D. R., C. D. Smith, and S. Wood. 2011. Agent-based model simulations of future changes in migration flows for Burkina Faso. Global Environmental Change 21:S34-S40. http://dx.doi.org/10.1016/j.gloenvcha.2011.09.006 
Magallanes, J. M., A. Burger, and C. Cioffi-Revilla. 2014. Understanding migration induced by climate change in the Central Andes of Peru via agent-based computational modeling. In J. Sichman, E. MacKerrow, F. Squazzoni, and T. Terano, editors. Proceedings of the 5th World Congress on Social Simulation. Sao Paolo, Brazil.

Mena, C. F., S. J. Walsh, B. G. Frizzelle, Y. Xiaozheng, and G. P. Malanson. 2011. Land use change on household farms in the Ecuadorian Amazon: design and implementation of an agent-based model. Applied Geography 31(1):210-222. http://dx.doi.org/10.1016/j.apgeog.2010.04.005

Naivinit, W., C. Le Page, G. Trébuil, and N. Gajaseni. 2010. Participatory agent-based modeling and simulation of rice production and labor migrations in northeast Thailand. Environmental Modelling \& Software 25(11):1345-1358. http://dx.doi.org/10.1016/j.envsoft.2010.01.012

Naqvi, A. A., and M. Rehm. 2014. A multi-agent model of a low income economy: simulating the distributional effects of natural disasters. Journal of Economic Interaction and Coordination 9(2):275-309. http://dx.doi.org/10.1007/s11403-014-0137-1

Rogers, D. S., O. Deshpande, and M. W. Feldman. 2011. The spread of inequality. PLoS ONE 6(9):e24683. http://dx.doi.org/10.1371/journal.pone.0024683

Smajgl, A., and E. Bohensky. 2013. Behaviour and space in agent-based modelling: poverty patterns in East Kalimantan, Indonesia. Environmental Modelling \& Software 45:8-14. http://dx.doi.org/10.1016/j.envsoft.2011.10.014

Smajgl, A., G. Carlin, A. House, J. Butler, E. Bohensky, A. S. Kurnia, C. Sugiyanto, and M. Hodgen. 2009. Design document for agent-based model SimPaSI Jawa Tengah. Simulating pathways to sustainability in Indonesia. CSIRO, Townsville, Australia.

Smajgl, A., S. Egan, M. Kirby, M. Mainuddin, J. Ward, and F. Kroon. 2013. The Mekong Region simulation (Mersim) model - design document. CSIRO Climate Adaptation Flagship, Townsville, Australia. 
Smajgl, A., J. Xu, S. Egan, Z.-F. Yi, J. Ward, and Y. Su. 2015a. Assessing the effectiveness of payments for ecosystem services for diversifying rubber in Yunnan, China. Environmental Modelling \& Software 69:187-195. http://dx.doi.org/10.1016/j.envsoft.2015.03.014

Smajgl, A., J. R. Ward, T. Foran, J. Dore, and S. Larson. 2015b. Visions, beliefs, and transformation: exploring cross-sector and transboundary dynamics in the wider Mekong region. Ecology and Society 20(2):15. http://dx.doi.org/10.5751/ES-07421-200215

Smith, C. D. 2014. Modelling migration futures: development and testing of the rainfalls agent-based migration model - Tanzania. Climate and Development 6(1):77-91. http://dx.doi.org/10.1080/17565529.2013.872593

Walsh, S. J., G. P. Malanson, B. Entwisle, R. R. Rindfuss, P. J. Mucha, B. W. Heumann, P. M. McDaniel, B. G. Frizzelle, A. M. Verdery, N. E. Williams, X. Yao, and D. Ding. 2013. Design of an agent-based model to examine population—environment interactions in Nang Rong $\begin{array}{llll}\text { District, } & \text { Thailand. } & \text { Applied } & \text { Geography }\end{array}$ http://dx.doi.org/10.1016/j.apgeog.2012.12.010

Wu, J., R. Mohamed, and Z. Wang. 2011. Agent-based simulation of the spatial evolution of the historical population in China. Journal of Historical Geography 37:12-21. http://dx.doi.org/10.1016/j.jhg.2010.03.006 